\title{
Searching for Common Ground in Evolving Canadian and EU Arctic Strategies
}

\author{
P. Whitney Lackenbauer and Suzanne Lalonde
}

\section{1 \\ Introduction}

In the beloved classic of English literature Pride and Prejudice, the heroine of the story, Miss Elizabeth Bennett, woefully misunderstands Mr. Darcy's character and motivations, wrongly believing him to be proud and disdainful following a series of rather unfortunate encounters early on in their acquaintance. As a result, opportunities very much to Miss Bennett's advantage are nearly lost.

The Canadian-EU Arctic relationship has also suffered from similar misconceptions; that is to say, from a lack of true understanding of "character, identity and motivations." And as with Jane Austen's tale, it may well be that Canada and the European Union have let early encounters skew their understanding and taint their vision of the other.

In Canada, the European Union's efforts to constructively engage in the Arctic have been met with scepticism and distrust. The supranational body's actions have been characterised in some quarters as irrelevant and, in others, as intrusive. A recent post on the "Eye on the Arctic" blog coordinated by Radio Canada International by Heather Exner-Pirot, a strategist for Outreach and Indigenous Engagement at the University of Saskatchewan, is representative. "The Eu keeps telling us it cares about the Arctic," she asserts. "I'm not sure the Arctic cares about it."

* $\quad$ P. Whitney Lackenbauer, Professor, Department of History and co-director of the Centre on Foreign Policy and Federalism at St. Jerome's University in the University of Waterloo, Canada.

** Suzanne Lalonde, Professor of International Law and the Law of the Sea, Faculty of Law, University of Montreal, Canada.

*** The authors wish to thank Tahnee Prior, a Trudeau scholar and PhD candidate at the Balsillie School for International Affairs, for research assistance and the exchange of ideas on an earlier iteration of this work.

1 Graham Greenleaf, 'The EU's Arctic policy-A means, not an end' (Eye on the Arctic, 3 May 2016) <http://www.rcinet.ca/eye-on-the-arctic/2016/05/o3/blog-the-eus-arctic-policy -a-means-not-an-end/> accessed 22 September 2016. 
On the European side, commentators argue that the EU is a "misunderstood Arctic actor." In turn, Canada's Arctic policy is often cast in a harsh light. The assessment of Dr. Andrew Foxall, director of the Russian Studies Centre at the London-based Henry Jackson Society, published in The Guardian in December 2013, is telling. "It's often said that the Russians act with their Arctic policy in an aggressive, nationalistic and unilateral way," Foxall suggests. "The same thing can be said about the Canadians." ${ }^{3}$ Kristine Offerdel of the Norwegian Institute for Defence Studies similarly refers to the "impression abroad of an aggressive Canadian Arctic policy" that continues to persist. ${ }^{4}$

These frames are increasingly relevant to the Canada-EU relationship as increasing global attention is directed towards the dramatic changes in the circumpolar Arctic. First and foremost, the Arctic has experienced some of the most rapid climate change impacts on Earth. For example, Canada has warmed twice as fast as the global average, and its North has warmed nearly three times as fast as the global average. This has generated accelerated thawing of permafrost, increased methane emissions, and major changes in ice and snow conditions. The much-discussed melting of Arctic sea ice holds out the prospect of a longer shipping season and improved navigability of Arctic waters, thereby enabling potential new access to mineral and energy resources, shipping, tourism, and commercial fishing. ${ }^{5}$ At the same time, members of the scientific and environmental communities raise concerns about a perceived rush to exploit natural resources of the Arctic Ocean. Such development, critics argue, is

2 Damien Degeorges, 'The Arctic: A region of the future for the European Union and the world economy' (2013) 263 European Issues, available on the website of the Fondation Robert Schuman <http://www.robert-schuman.eu/en/doc/questions-d-europe/qe-263-en .pdf>, accessed 26 October 2016.

3 Luke Harding, 'Russia to boost military presence in Arctic as Canada plots north pole claim' (The Guardian, 10 December 2013) <http://www.theguardian.com/world/2013/dec/10/russiamilitary-arctic-canada-north-pole $>$ accessed 22 September 2016.

4 Kristine Offerdel, 'Interstate Relations: the complexities of Arctic politics' in Rolf Tamnes and Kristine Offerdel (eds), Geopolitics and Security in the Arctic (Routledge, New York 2014) 73, at p. 75 .

5 Various authors continue to emphasize the ongoing challenges to shipping in the Northwest Passage. For recent summaries, see Adam Lajeunesse and P. Whitney Lackenbauer, On Uncertain Ice: The Future of Arctic Shipping and the Northwest Passage (Canadian Defence \& Foreign Affairs Institute, Calgary 2014); Buixadé Farré and others 'Commercial Arctic shipping through the Northeast Passage: routes, resources, governance, technology, and infrastructure' (2014) 37 (4) Polar Geography 298, 324; and Frédéric Lasserre and Olga Alexeeva, 'Analysis of maritime transit trends in the Arctic passages' in Suzanne Lalonde and Ted McDorman (eds), International Law and Politics of the Arctic Ocean: Essays in Honor of Donat Pharand (Brill, Leiden 2015). 
incommensurate with efforts to limit average global warming to $2^{\circ} \mathrm{C} .{ }^{6}$ These new activities may also threaten the marine environment, negatively impacting both ecosystems and the traditional livelihoods of Indigenous peoples and northern communities.

In the face of rapid environmental change and accelerating international interest in the Arctic, current approaches to regional governance aggregate multiple understandings and visions for the circumpolar North. A notion of multiple Arctics - North American, Northern European, and Russianpoints to both convergence and discordance in how different regional actors perceive the North. As Professor Carina Keskitalo of Umeå University observes, "Canada developed a specific understanding of its 'Arctic' quite early" that went beyond the Arctic Ocean and its immediate vicinity to encompass its entire Northern territories above $60^{\circ}$ North latitude as "Arctic." At the end of the Cold War, when Canada played a leading role in political negotiations to institutionalize circumpolar relations, its particular understanding of the Arctic in environmental and human terms (rooted in Indigenous subsistencebased livelihoods) deeply influenced the region-building process. Accordingly, Canada's "historically developed notions of 'the Arctic' have been transplanted to northern areas everywhere, with little reflection on whether it is applicable to the different regions or not."7

As an Arctic coastal State with $40 \%$ of its landmass north of $60^{\circ}$ latitude and $162,000 \mathrm{~km}$ of its coastline in the Arctic, Canada's concern with effectively exercising its sovereignty is understandable. Its emphasis on the human dimensions of the Arctic, and particularly those related to the northern Indigenous peoples, also reflects national realities. Its three northern territories (Yukon, Northwest Territories, and Nunavut) are home to just over 110,000 people (more than half of whom are Indigenous or Aboriginal), spread out in remote communities. Social indicators in Canada's North are abysmal, pointing to

6 The Paris Agreement signed on 12 December 2015 seeks to limit global warming to "well below $2^{\circ} \mathrm{C}$ above pre-industrial levels and pursuing efforts to limit the temperature increase to $1.5^{\circ} \mathrm{C}$." For examples of scepticism that this can be met, see Cristophe McGlade and Paul Elkins, 'The geographical distribution of fossil fuels unused when limiting global warming to $2^{\circ} \mathrm{C}^{\prime}$ [2013] 517 Nature 187, 90 and Climate Central, 'Earth Flirts with a 1.5-Degree Celsius Global Warming Threshold' (Scientific American, 20 April 2016) <http://www.scientific american.com/article/earth-flirts-with-a-1-5-degree-celsius-global-warming-threshold1/> accessed 22 September 2016.

7 Corinna Röver, Interview with Carina Keskitalo, 'The notion of the 'Arctic' is based on Canadian ideas, according to discourse analysis study' SciencePoles (2014). See also E.C.H. Keskitalo, Negotiating the Arctic: The Construction of an International Region (New York: Routledge 2004). 
the challenges of providing social services and infrastructure to small and remote communities. Indigenous peoples, in particular, have experienced numerous challenges associated with rapid changes to their homelands, including threats to language and culture, erosion of traditional support networks, poorer health than the rest of Canadians, and changes to traditional diet and communal food practices. ${ }^{8}$ Rich in natural resources, but geographically distant from major markets, the North has long served as an economic "land of tomorrow" in the Canadian political imagination. ${ }^{9}$ Buoyed by the prospect of heightened global demand and new access to resources, boosters have trumpeted the Arctic's "coming of age" in the early twenty-first century. This has rejuvenated national interest in Northern affairs, as well as resurrecting longstanding anxieties about sovereignty, security (in its many dimensions), and the well-being of Northern Canadians. ${ }^{10}$

Canada's propensity to project its domestic northern strategy, which is deeply embedded in North American Arctic priorities, into the circumpolar sphere should come as no surprise owing to its success in deeply institutionalizing its conception of the Arctic in current instruments of Arctic governance. Canadian politicians and commentators often trumpet how their country led efforts to establish the Arctic Council through the 1996 Ottawa Declaration, which reflected Canada's preoccupations with the environment and Indigenous peoples, ${ }^{11}$ and served as the Council's first Chair (1996-1998). Canada's recent chairmanship of the Arctic Council (2013-15) also reflected a strong emphasis

8 See, for example, Indigenous and Northern Affairs Canada, 'The Community WellBeing (сшв) Index' <https://www.aadnc-aandc.gc.ca/eng/1100100016579/1100100016580> accessed 25 September 2016, National Aboriginal Health Organization, 'Overview of Inuit Health' <http://www.naho.ca/inuit/overview-of-inuit-health/> accessed 25 September 2016; and Nordic Council of Ministers, Arctic Social Indicators: ASI II: Implementation (TemaNord, Nordic Council of Ministers, Copenhagen 2015).

See, for example, D.M. LeBourdais, 'Land of Tomorrow: Arctic Is a Land of Promise Which We Must Hold' (1938) 89 Canadian Magazine 18, 37, 38 and Sherrill Grace, Canada and the Idea of North (McGill-Queen's University Press, Montreal \& Kingston 2007).

10 On popular opinion and the Arctic, see the Munk-Gordon Arctic Security Program, 'Rethinking the Top of the World: Arctic Public Opinion Survey' reports: vol. 1: 2011 <http://gordonfoundation.ca/publication/300> accessed 26 October 2016 and vol. 2: 2015 $<$ http://gordonfoundation.ca/publication/755> accessed 26 October 2016. On changing definitions of sovereignty and security, see Wilfrid Greaves and Whitney Lackenbauer, 'Arctic Sovereignty and Security: Updating our Ideas' (OpenCanada 23 March 2016) <https://www.opencanada.org/features/re-thinking-sovereignty-and-security-arctic/> accessed 26 October 2016.

11 See, for example, Thomas Axworthy and Ryan Dean, 'Changing the Arctic Paradigm from Cold War to Cooperation: How Canada's Indigenous Leaders Shaped the Arctic Council' 
on Northern Indigenous peoples, prompting some commentators to lament its domestic (rather than global) orientation, its comparative lack of emphasis on science and research, and its suggestion that non-Northerners had a limited role to play in agenda-setting or circumpolar dialogue. ${ }^{12}$

Furthermore, as a result of geography and history, it is unsurprising that Canada considers the United States its "premier partner" in Arctic affairs. ${ }^{13}$ Although academic and popular commentary often highlights disagreements between these North American neighbours over the status of the waters of the Northwest Passage (NWP) and the maritime boundary in the Beaufort Sea, the common interests of both countries have provided a firm foundation for strong cooperation in the Arctic region. In March 2016, President Barack Obama and Prime Minister Justin Trudeau offered a U.s.-Canada Joint Statement on Climate, Energy, and Arctic Leadership that articulated a common North American commitment to "play a leadership role internationally in the low carbon global economy over the coming decades, including through science-based steps to protect the Arctic and its peoples." This "new partnership" seeks to "embrace the opportunities and to confront the challenges in the changing Arctic, with Indigenous and Northern partnerships, and responsible, science-based leadership."14 While this statement affirms a bilateral "special relationship" between the two countries, it also suggests a leadership agenda that resonates with that of the European Union. Although the EU's recent integrated strategy focuses on the European Arctic (as well as Greenland, given its relationship with Denmark), ${ }^{15}$ its fundamental priorities are consisted with those of the North American Arctic States.

This chapter begins with an overview of Canada's historical engagement with the Arctic and the development of its Northern Strategy, explaining why

[2013] 5 (1) The Yearbook of Polar Law Online, 7-43, and John English, Ice and Water: Politics Peoples and the Arctic Council (Penguin Canada, Toronto 2013).

12 For a sample of these views, see Heather Exner-Pirot, 'Canada's Arctic Council chairmanship (2013-2015): a post-mortem' (2016) 22 (1) Canadian Foreign Policy Journal, 87, 88.

13 On these theme, see P. Whitney Lackenbauer and Rob Huebert, 'Premier Partners: Canada, the United States and Arctic Security' (2014) 20 (3) Canadian Foreign Policy Journal, 320, 33 .

14 Prime Minister of Canada 'U.S.-Canada Joint Statement on Climate, Energy, and Arctic Leadership' (Justin Trudeau, Prime Minister of Canada) <http://www.pm.gc .ca/eng/news/2016/o3/10/us-canada-joint-statement-climate-energy-and-arctic-leader ship\#sthash.XjRoT2R7.dpuf> accessed 25 September 2016.

15 European Commission (EC), 'Joint Communication to the European Parliament and the Council: An integrated European Union policy for the Arctic (hereafter "Joint Communication")' JOIN (2016) 21. 
it places a high priority on sovereignty, economic development for the benefit of Northerners, environmental protection, and governance (particularly by Arctic States and Northern Indigenous peoples). Building on this foundation, we seek to bring the Arctic policies of Canada and the EU into dialogue, highlighting critical interests and issue areas such as the environment and climate change, transport, energy, mineral resources, fisheries, and research. While we argue that evolving policy positions point towards an increasingly convergent, cooperative agenda between Canada and the EU on Arctic issues, divergent interests and messaging associated with shipping and freedom of the seas/ navigation rights, the rights of Indigenous peoples and the trade in marine mammals, resource development and environmental stewardship could continue to complicate the relationship.

\section{2 Canada's Northern Interests: Historical Developments}

Although the vast majority of Canadians live close to the country's southern border (the 49th parallel) with the United States, the Arctic occupies a distinctive place in Canada's national identity. Rich symbolism, imagery and mythology in Canada casts the Arctic as a resource-rich "frontier of destiny," a homeland for Indigenous peoples, a fragile environment in need of protection, and a source of national inspiration. Accordingly, Canada's historic and ongoing dilemma is how to balance sovereignty, security and stewardship in a manner that protects and projects national interests and values, promotes sustainable development and healthy communities, and facilitates circumpolar stability and cooperation. ${ }^{16}$

Inuit and other Northern Indigenous groups have occupied what is now the Canadian North since "time immemorial." As hunter-gatherer societies, their use and occupancy of the lands and waters form a core consideration of what is now widely accepted to constitute Canadian sovereignty. Accordingly, Canada has a recognized legal duty to consult and, where appropriate, accommodate Indigenous groups when their treaty and Aboriginal rights could be impacted. Their inter-connectedness with the land poses special obligations on the Canadian state to ensure that its practices are representative of their rights, interests, and wishes as recognized in both domestic and international law. Furthermore, these Indigenous peoples are transnational in that their

16 For an introduction to these themes, see Franklyn Griffiths, Rob Huebert, and P. Whitney Lackenbauer, Canada and the Changing Arctic: Sovereignty, Security, and Stewardship (Wilfrid Laurier University Press, Waterloo 2011). 
memberships include citizens of two or more countries. This is reflected in the Permanent Participant organizations representing them at the Arctic Council today. The Inuit Circumpolar Council (ICC), an N GO that formed in 1977 (nearly two decades before the Council), represents 155,000 Inuit of Chukotka (Russia), Alaska, Canada, and Greenland (Denmark), including just over 50,0oo Inuit Canadians. The Gwich'in Council International (GCI) represents the Gwich'in peoples who live in the northernmost third of Yukon and adjacent areas in Alaska and the Northwest Territories. The Arctic Athabaskan Council (AAC) represents 30,000 people of Athabaskan descent who live in Northern Canada and Alaska, with Canadian AAC members including the Dene Nation, the Council of Yukon First Nations, and the Metis Nation of the NwT. Cumulatively, the ongoing vitality of Northern Indigenous peoples makes them an influential force in Canadian domestic politics and in international norm-making in the Arctic more generally. ${ }^{17}$

Apart from short-lived Norse settlements around the turn of the first millenium CE, the earliest European interest in what is now the Canadian North fixated on trying to find a route through the region to reach the riches of Asia. The attempts to navigate through the icy labyrinth of islands north of the Canadian mainland from the sixteenth through the nineteenth centuries proved futile, however, and the much-sought after Northwest Passage did not materialize as a feasible commercial frontier. Instead, the fur trade drew both French and English interests further into the northern reaches of the continental mainland. This economic activity played a pivotal role in forging relationships between Indigenous and Euro-Canadian peoples, eventually supplemented by the presence of missionaries, whalers, policemen, and the sporadic appearance of explorers. The British Royal Navy resumed its quest to establish a Northwest Passage in the nineteenth century, and while the search for Sir John Franklin's ill-fated 1845 expedition proved the existence of an Arctic maritime route it also demonstrated its lack of utility. After Confederation in 1867, Euro-Canadians invested their resources and energies into establishing east-west linkages to

17 See, for example, Natalia Loukacheva, The Arctic Promise: Legal and Political Autonomy of Greenland and Nunavut (University of Toronto Press, Toronto 2007); Sonia Lawrence and Patrick Macklem, 'From consultation to reconciliation: Aboriginal rights and the Crown's duty to consult' [2000] 29 Can. B. Rev. 252; Canada, 'Aboriginal Consultation and Accommodation-Updated Guidelines for Federal Officials to Fulfill the Duty to Consult' (Canada, March 2011), <http://www.aadnc-aandc.gc.ca/eng/1100100014664/110010001467> accessed 29 October 2016; and Timo Koivurova and Leena Heinämäki, 'The participation of indigenous peoples in international norm-making in the Arctic' [2006] 42 (221) Polar Record 101-110. 
consolidate the Dominion of Canada. The northern limits of the young country, inherited from the Hudson's Bay Company in 1870 , remained ambiguous, and defining them seemed a remote, future consideration. ${ }^{18}$

Canada inherited whatever rights Great Britain had to the High Arctic in 1880, but governed its northern territories in a "fit of absence of mind" until after the Second World War. The Alaska Boundary Dispute between Canada and the United States suggested, in the minds of Canadians, that not only did the United States cast covetous eyes at Canada's Northern territories but that Britain would sell out our interests to court American goodwill. ${ }^{19}$ The Government of Canada would have to defend its own national interests in the North. The Klondike Gold Rush prompted the first official assertions of authority in the form of the Northwest Mounted Police and a small field force sent to the region around the turn of the twentieth century, but the expansion of official state activity into the region remained modest before the Second World War. Official expeditions into the Northwest Passage, matched by flag planting and asserting a Canadian "sector claim" up to the North Pole, were complemented by diplomatic activities to confirm Canadian sovereignty over the islands of Canada's Arctic archipelago. ${ }^{20}$ The delivery of services to Inuit and other Northern Indigenous groups remained minimal, however, with the government preferring to leave responsibilities for welfare and education to the Hudson's Bay Company and missionaries, and only half-heartedly resourcing assimiliationist programs such as residential schools. Instead, the prevailing logic that Indigenous peoples were "best left as Indians" prevailed

18 For a sweeping overview, see Shelagh Grant, Polar imperative: A History of Arctic Sovereignty in North America (Douglas \& McIntyre Publishers, Vancouver 2011).

19 The Alaska Boundary dispute, which was resolved by arbitration in 1903, concerned the boundary between the Alaska panhandle and British Columbia. Britain still handled Canada's foreign affairs at the time, and one of three Canadian arbitrators-Lord Alverstone, Lord Chief Justice of England—sided with the Americans in drawing a line that was considerably closer to the American position than to the Canadian. This ignited a firestorm of criticism in Canada amongst nationalists who believed that Alverstone had supported the Americans because Britain, worried about the growing military power of Germany, had sacrificed Canadian interests to bolster Anglo-American relations. See John A. Munro, eds, The Alaska Boundary Dispute (Copp Clark Publishing Company, Toronto 1970).

20 On sovereignty in the Canadian Arctic before the Second World War, see Gordon W. Smith, A Historical and Legal Study of Sovereignty in the Canadian North: Terrestrial Sovereignty, 1870-1939, P.W. Lackenbauer (ed), (University of Calgary Press, Calgary 2014). 
until after the Second World War. ${ }^{21}$ Accordingly, the Northern Native economy remained rooted in subsistence hunting and the fur trade, while discoveries of oil, gold, and pitchblend (the mineral from which radium is extracted) prompted the emergence of a mining economy for non-Native Canadians in the Northwest Territories (NWT).

The Second World War ushered in the new idea that the Canadian North also represented a military frontier. The American imperative to build the Alaska Highway through the Canadian Northwest, as well as supporting airfields and an oil pipeline, brought a flurry of new activity into the region. Although undertaken in the name of continental security, these activities also resurrected fears about the United States' encroachment on Canadian sovereignty in this sparsely-populated corner of North America. ${ }^{22}$ The Americans withdrew at the end of the war and confirmed Canadian ownership over the Yukon and the infrastructure built therein, but visions of a looming Cold War provided a primary impetus for another round of military-inspired development beginning in the late 1940s. The dictates of geography placed the Arctic at the centre of Cold War superpower geopolitics, and in popular opinion and in the eyes of some Canadian officials, the American security agenda again seemed to pose a potential threat to Canada's sovereignty. In the end, however, the North American neighbours found solutions that affirmed Canada's terrestrial sovereignty. ${ }^{23}$ On the other hand, the American behemoth largely dictated the pace of military modernization in Canada's North throughout the

21 See, for example, Ken Coates, Best Left as Indians: Native-White Relations in the Yukon Territory, 1840-1973 (McGill-Queen's University Press, Kingston \& Montreal, 1991) and William R. Morrison, 'Canadian sovereignty and the Inuit of the central and eastern Arctic' (1986) 10 (1) Études/Inuit/Studies, 245-259.

See Kenneth Coates and William R. Morrison, The Alaska Highway in World War II: The US Army of Occupation in Canada's Northwest (University of Oklahoma Press, Norman 1992) and Shelagh Grant, Sovereignty or Security? Government Policy in the Canadian North, 1936-1950 (U BC Press, Vancouver 1988).

23 See, for example, P. Whitney Lackenbauer, 'Right and Honourable: Mackenzie King, Canadian-American Bilateral Relations, and Canadian Sovereignty in the Northwest, 1943-1948' in John English, Kenneth McLaughlin, and P.W. Lackenbauer (eds), Mackenzie King: Citizenship and Community (Robin Brass Studio, Toronto 2002) 151-68, and Lackenbauer and Peter Kikkert, 'Sovereignty and Security: The Department of External Affairs, the United States, and Arctic Sovereignty, 1945-68' in Greg Donaghy and Michael Carroll (eds), In the National Interest: Canadian Foreign Policy and the Department of Foreign Affairs and International Trade, 1909-2009 (University of Calgary Press, Calgary 2011) 101-20. 
1950s and the major socio-economic, cultural, and environmental impacts that flowed from it.

During this era, Canadian officials began to awaken to the federal government's obligations to Northern residents. The introduction of the Canadian social welfare system meant that Indigenous Canadians now had access to a wide array of programs, from family allowances to old-age pensions, and then housing, schooling, health care, and economic development grants. As a result, the federal government became increasingly involved in the lives of Northerners at a time of tremendous socio-political change. To seek wage employment at military installations or to receive government services, Northern Indigenous peoples (particularly Inuit) who had followed a seasonal cycle, living off the land hunting and fishing since time immemorial, were drawn into small permanent communities sprinkled across the North. As a result, by the late 196os the vast majority of Indigenous peoples no longer lived in tents or igloos (snow-houses) but in government housing. ${ }^{24}$ "In communities, traditional methods of subsistence were difficult for Inuit to maintain because of the lengthy travel distances required to find animal resources, and the need to maintain a steady family income through wage employment," historian Sarah Bonesteel explains. ${ }^{25}$ Although federal programs hoped to improve living standards through a diversified economy that would offer wage labour opportunities in industries such as mining as well as the continuation of the subsistence economy, the result of the transition to sedentary, settlement-based living was to produce cultural dislocation and wide-sweeping economic dependency.

The role of the Northern frontier in Canada's future economic prosperity grew in the twentieth century, as Canadians awakened to the idea of exploiting the region's abundant natural resources. Geological Survey of Canada mapping operations in the early postwar period "discovered" gold, silver, nickel, zinc, lead, molybdenum and asbestos in the NWT districts of Keewatin and Mackenzie, leading to the opening of new mines. Exploration in the 196os shifted to base metals around Great Bear Lake. By that time, Prime Minister John Diefenbaker had articulated a new "northern vision" for Canada that promised "roads to resources" and would generate national prosperity. Only partially implemented, this plan did not extend to the High Arctic or realize the high

24 On this process, see David Damas, Arctic Migrants/Arctic Villagers: The Transformation of Inuit Settlement in the Central Arctic (McGill-Queen's University Press, Montreal \& Kingston 2002).

25 Sarah Bonesteel, Canada's Relationship with Inuit: A History of Policy and Program Development (Indian and Northern Affairs Canada, Ottawa 2008). 
expectations for economic development in Canada's northern territories. Over time, however, mining developments extended to Canada's archipelago, with a lead-zinc mine at Nanisivik on Baffin Island opening in 1976 and the Polaris lead-zinc mine on Little Cornwallis Island that started production in $1982 .{ }^{26}$

Economic development became intertwined with issues of sovereignty, Indigenous rights, and environmentalism in the context of oil and gas exploration. The discovery of the Prudhoe Bay field off the north slope of Alaska in 1968 set off an Arctic exploration boom that persisted until oil prices declined precipitously in the mid-1980s. ${ }^{27}$ The viability of these northern projects depended upon the ability to transport resources to market. In 1969, Americanowned Humble Oil sent an icebreaker, the Manhattan, through the Northwest Passage to determine whether it was a viable commercial shipping route for oil and gas from the Beaufort Sea. In response, the Canadian media reported the voyage as a direct challenge to Canada's Arctic sovereignty. In response, the Liberal government of Pierre Trudeau announced its "functional" approach to Canadian sovereignty in 1970 . It cast the Arctic as an ecologically delicate region: Canada needed to extend its jurisdiction northward to ensure that foreign vessels did not pollute Canadian waters. The Arctic Waters Pollution Prevention Act (AWPPA) allowed Canada to regulate and control future tanker traffic through the NWP by creating a pollution prevention zone one hundred nautical miles outside the archipelago as well as in the waters between the islands. ${ }^{28}$ Although initially opposed to this unilateral measure, the United States supported Canadian-sponsored Article 234 in the 1982 UN Convention on the Law of the Sea (UNCLOS), which gives coastal States "the right to adopt

26 W.W. Nassichuk, 'Forty years of northern non-renewable natural resource development' (1987) 275 Arctic. On Diefenbaker's Northern Vision, see P. Isard, 'Northern Vision: Northern Development during the Diefenbaker Era' (unpublished M.A. thesis, University of Waterloo, 2010).

27 The Norman Wells field had yielded petroleum since the 1920s, but exploration in the northern Yukon, Mackenzie Delta, and High Arctic islands began in the 1950s. On oil and gas activities in the 1970 and 8 os, see Robert Page, Northern Development: The Canadian Dilemma (McClelland \& Stewart, Toronto 1986).

28 The AWPPA (1970, R.s.C. 1985) and its regulations provides specific construction standards for vessels engaged in Arctic shipping, a system of shipping safety control zones, a ban on discharges of oil, hazardous chemicals, and garbage, and requirements for vessels to carry insurance to cover damages from any these discharges. On this period, see J. Alan Beesley, 'Rights and responsibilities of Arctic coastal states: the Canadian view' (1971) 3 Journal of Maritime Law \& Commerce 1, and Ted McDorman, Salt Water Neighbors: International Ocean Law Relations Between the United States and Canada (Oxford University Press, Oxford 2009). 
and enforce non-discriminatory laws and regulations for the prevention, reduction and control of marine pollution from vessels in ice-covered areas within the limits of the exclusive economic zone."29

Alongside environmental considerations encouraging Canadians to reconceptualize the Arctic as mere frontier space to a place in need of protection, the idea of the Arctic as homeland gained greater political salience in the Canadian dialogue on development in the 1970s. Indigenous groups had reemerged as a political force in Canada, and Northern Native leaders would no longer tolerate being left out of discussions related to resource development in their traditional territories. The Berger Inquiry, conducted to look into the socio-economic and environmental impact of a pipeline along the Mackenzie Valley through the Yukon and NWT, elicited unprecedented public engagement on a frontier development project before it began. Justice Thomas Berger's final report, Northern Frontier, Northern Homeland, highlighted competing visions of Canada's Northern history and the future. "We look upon the North as our last frontier," he noted of the southern Canadian view. "It is natural for us to think of developing it, of subduing the land and extracting its resources to fuel Canada's industry and heat our homes. But the native people say the North is their homeland. They have lived there for thousands of years. They claim it is their land, and they believe they have a right to say what its future ought to be." Berger recommended a ten-year moratorium on any pipeline development so that Aboriginal land claims could be settled and appropriate conservation areas established beforehand. ${ }^{30}$ Thus, internal sovereignty claims by Canadian Indigenous groups changed the political dialogue, and Canada embarked upon a process of settling comprehensive land claims with Northern Indigenous peoples whose land rights had not been dealt with by treaty or other legal means - a process that has dramatically transformed Canada's political landscape and remains ongoing today. ${ }^{31}$

29 See Don McRae, 'The negotiation of Article 234' in Franklyn Griffiths (eds), Politics of the Northwest Passage (McGill-Queen's University Press, Montreal \& Kingston 1987) 98-114, and Rob Huebert, 'Article 234 and Marine Pollution Jurisdiction in the Arctic' in Don Rothwell and Alex Oude Elferink (eds), The Law of the Sea in the Polar Oceans: Issues of Maritime Delimitation and Jurisdiction (Kluwer, Dordrecht, 2001) 249-267.

30 Thomas R. Berger, Northern Frontier, Northern Homeland: The Report of the Mackenzie Valley Pipeline Inquiry vol. 1 (Minister of Supply and Services Canada, Ottawa 1977) 1. See also Canadian Broadcasting Corporation (свС) archives, 'The Berger Pipeline Inquiry' ( С BC News) <http://archives.cbc.ca/IDD-1-73-295/politics_economy/pipeline/> accessed 26 October 2016, and Martin O'Malley, The Past and Future Land:An Account of the Berger Inquiry into the Mackenzie Valley Pipeline (P. Martin Associates Ltd., Toronto 1976).

31 See, for example, Kirk Cameron and Graham White, Northern governments in transition: Political and constitutional development in the Yukon, Nunavut and the Western 
Domestic drivers dominated the Canadian political agenda for most of the 1970 and early 1980s, but the external dimensions of sovereignty re-emerged with the August 1985 voyage of the us Coast Guard icebreaker Polar Sea through the Northwest Passage. Although launched for reasonable operational reasons relating to the resupply of the American base at Thule, Greenland, the Americans refused to seek official permission from Canada, recognizing that this would prejudice their own legal position on international straits globally. In response, the Conservative government of Brian Mulroney announced that Canada was officially drawing straight baselines around the Arctic Archipelago effective 1 January 1986, thus confirming Canada's sovereignty over the NWP as "historic, internal waters." Concurrently, it outlined an aggressive plan to exercise control over its waters and assert its Arctic sovereignty. ${ }^{32}$ Canada also promised to negotiate with the United States-a prudent move that, owing to Prime Minister Mulroney's close relationship with President Ronald Reagan, yielded the 1988 Arctic Cooperation Agreement under which, in the interests of safe navigation, the "United States pledges that all navigation by U.s. icebreakers within waters claimed by Canada to be internal will be undertaken with the consent of the Government of Canada." By "agreeing to disagree" on the legal status of the passage, the two countries reached "a pragmatic solution based on our special bilateral relationship, our common interest in cooperating on Arctic matters, and the nature of the area" — one that did not prejudice either country's legal position or set a precedent for other areas of the world. ${ }^{33}$ With this understanding in place and the perceived "crisis" averted, Canadian political attention associated with Arctic sovereignty faded once again.

With the end of the Cold War, the official discourse in Canada on Arctic affairs shifted away from continental security and narrow sovereignty interests to emphasize circumpolar cooperation and broad definitions of security that prioritized human and environmental dimensions. Canada was an early champion of the Arctic Council and promoted the inclusion of Indigenous

Northwest Territories (Institute for Research on Public Policy, Montreal 1995); Christopher Alcantara, 'To treaty or not to treaty? Aboriginal peoples and comprehensive land claims negotiations in Canada' [2008] 38 (2) Publius: The Journal of Federalism 343-369; and Greg Poelzer and Ken S. Coates, From Treaty Peoples to Treaty Nation: A Road Map for All Canadians (UBC Press, Vancouver 2015).

32 See Rob Huebert, 'Polar vision or tunnel vision the making of Canadian Arctic waters policy: The making of Canadian Arctic waters policy' [1995] 19 (4) Marine Policy 343-363, and Huebert, 'A Northern Foreign Policy: The Politics of Ad Hocery' in Kim Nossal and Nelson Michaud (eds), Diplomatic Departures: The Conservative Era in Canadian Foreign Policy, 1984-1993 (UBC Press, Vancouver 2001) 84-99.

33 Christopher Kirkey, 'Smoothing troubled waters: the 1988 Canada-United States Arctic co-operation agreement' [1995] 50 (2) International Journal 401-426. 
Permanent Participants with a seat at the table. In 1997, a Canadian parliamentary committee recommended that the country should focus on international Arctic cooperation through multilateral governance to address pressing "human security" and environmental challenges in the region. Committee chairman Bill Graham reported that environmentally sustainable human development was "the long-term foundation for assuring circumpolar security, with priority being given to the well-being of Arctic peoples and to safeguarding northern habitants from intrusions which have impinged aggressively on them." ${ }^{34}$ The Liberal government under Jean Chrétien (1993-2003) embraced this emphasis on international cooperation, and The Northern Dimension of Canada's Foreign Policy released in 2000 revealed how environmental and social challenges now predominated:

Both the tradition of transnational co-operation and the new emphasis on human security are particularly applicable to the shaping of the Northern Dimension of Canada's Foreign Policy. The circumpolar world that includes the northern territories and peoples of Canada, Russia, the United States, the Nordic countries plus the vast (and mostly ice-covered) waters in between was long a front line in the Cold War. Now it has become a front line in a different way-facing the challenges and opportunities brought on by new trends and developments. The challenges mostly take the shape of transboundary environmental threats-persistent organic pollutants, climate change, nuclear waste- that are having dangerously increasing impacts on the health and vitality of human beings, northern lands, waters and animal life. The opportunities are driven by increasingly confident northern societies who, drawing on their traditional values, stand poised to take up the challenges presented by globalization. Whereas the politics of the Cold War dictated that the Arctic region be treated as part of a broader strategy of exclusion and confrontation, now the politics of globalization and power diffusion highlight the importance of the circumpolar world as an area for inclusion and co-operation. ${ }^{35}$

34 House of Commons Standing Committee on Foreign Affairs and International Trade (hCscfait), Canada and the Circumpolar World: Meeting the Challenges of Cooperation into the Twenty-First Century (1997), ix, 100.

35 Canada, The Northern Dimension of Canada's Foreign Policy (Department of Foreign Affairs and International Trade, Ottawa 200o). 
Framed by principles of Canadian leadership, partnership, and ongoing dialogue with Northerners, this new northern foreign policy was rooted in four overarching objectives: to enhance the security and prosperity of Canadians, especially Northerners and Aboriginal peoples; to assert and ensure the preservation of Canada's sovereignty in the North; to establish the Circumpolar region as a vibrant geopolitical entity integrated into a rules-based international system; and to promote the human security of Northerners and the sustainable development of the Arctic.

By the start of the new millennium, developments in Aboriginal selfgovernment and devolution required new economic opportunities that promoted northern interests. Similarly, asserting and ensuring the preservation of Canadian sovereignty was deemed compatible with multilateral cooperation. The focus on diplomacy and circumpolar cooperation meant that traditional preoccupations with "defending" sovereignty slipped to the back burner. The 2000 Canadian Forces' Arctic Capabilities Study recognized that Northern security had evolved to include environmental, social, and economic aspects, but argued that the coming decades would make the region even more vulnerable to "asymmetric" security and sovereignty threats. Accordingly, it argued that the Canadian Forces had to prepare to respond to challenges related to environmental protection, increased shipping as Arctic sea lanes opened due to climate change, heightened commercial airline activity, and "trans-national criminal activity" that would accompany resource development such as diamond mining. ${ }^{36}$ These frames, accentuated by the rising tide of evidence about the pace and impacts of global warming in the Arctic, led Canadian journalists and academic commentators to push in the early 2000 for a more proactive Arctic strategy that anticipated emerging security challenges associated with climate change, boundary disputes like Hans Island, the contested status of the waters of the Northwest Passage for international transit shipping, resource development, and heightened international activity in the region more generally. ${ }^{37}$

In December 2004, Paul Martin's Liberal Government announced an integrated Northern Strategy (devised in concert with the premiers of the Northern territories of Yukon, Northwest Territories, and Nunavut-a new, predominantly Inuit jurisdiction created in 1999) built around seven main goals. First, the strategy promised to strengthen Northern governance, partnerships and

\footnotetext{
36 Canadian Forces Northern Area (CFNA), Arctic Capabilities Study (Yellowknife 2000).

37 Rob Huebert, 'Climate Change and Canadian Sovereignty in the Northwest Passage' [2001] Isuma: Canadian Journal of Policy Research 2 (4); See, in particular, the Arctic Climate Impact Assessment (2004).
} 
institutions to provide Northerners with greater control over decisions about their future. Second, it committed to establishing strong foundations for "strong, sustainable, diversified economies where northerners share in the benefits of northern development." Third, it proposed "to engage all partners in the North in the protection and stewardship of the environment." Fourth, it sought to promote "healthy, safe and sustainable northern communities" that would "promote self-reliance." Fifth, the document committed to ensuring that Canada would continue to play a "leading role" in promoting international cooperation, while taking Northerners' concerns into "consideration in national efforts to reinforce sovereignty, security and circumpolar cooperation." Sixth, the strategy promised to preserve, revitalize, and promote Indigenous cultures, recognizing and encouraging "the importance of language, traditional knowledge and way-of-life." Seventh, the government committed to ensuring that "Canada is a leader in northern science and technology, and to develop expertise in areas of particular importance and relevance to the North." Although the Martin government conducted public consultations on the strategy in 2005, the results were not released before the federal election at the end of that year which saw a change in government. ${ }^{38}$

In 2005, the Liberal Government's International Policy Statement (IPS) also identified the Arctic as a priority area in light of "increased security threats, a changed distribution of global power, challenges to existing international institutions, and transformation of the global economy." It was anticipated that the next two decades would bring major challenges requiring creative diplomacy as well as investments in new defence capabilities. "In addition to growing economic activity in the Arctic region, the effects of climate change are expected to open up our Arctic waters to commercial traffic by as early as 2015," the new policy stated. "These developments reinforce the need for Canada to monitor and control events in its sovereign territory, through new funding and new tools." ${ }^{39}$ Although the Liberal government fell before it could implement its vision, it had intertwined sovereignty and security in political rhetoric and strategic documents.

38 See Canadian Arctic Resources Committee, 'Renewing the Northern Strategy' [2006] 30 (1) Northern Perspectives 2.

39 The IPs focused on surveillance, such as infrared sensors for patrol aircraft, unmanned aerial vehicles, and satellites. Canada, Canada's International Policy Statement, Overview (2005), excerpted in Ryan Dean, P. Whitney Lackenbauer, and Adam Lajeunesse, Canadian Arctic Defence and Security Policy: An Overview of Key Documents, 1970-2012 (Centre for Military and Strategic Studies/Centre on Foreign Policy and Federalism, 2014 Calgary and Waterloo) 39-40. 
It fell to the Conservatives, who came to office in January 2006, to implement this agenda and to make Arctic sovereignty and security a major political priority. The Canadian North was a key component of the Conservatives' 2005 election platform, which played on the idea of an Arctic sovereignty "crisis" demanding decisive action. Stephen Harper promised that Canada would acquire the military capabilities necessary to defend its sovereignty against external threats. "The single most important duty of the federal government is to defend and protect our national sovereignty," Harper asserted. "It's time to act to defend Canadian sovereignty. A Conservative government will make the military investments needed to secure our borders. You don't defend national sovereignty with flags, cheap election rhetoric, and advertising campaigns. You need forces on the ground, ships in the sea, and proper surveillance. And that will be the Conservative approach." 40 In short, the new prime minister's political message emphasized the need for Canadian action with a particular attention to conventional military forces, differentiating his government from the Liberals whom he believed had swung the pendulum too far towards diplomacy and human development.

The government's "use it or lose it" approach to Arctic policy dominated the agenda from 2006-09. A spate of commitments to invest in military capabilities to defend Canada's rights in the region, including new Arctic patrol vessels and more vigorous patrolling, reinforced the government's emphasis on "hard security" rather than "human security" like its predecessors. ${ }^{41}$ This formulation offered little political incentive to downplay the probability of military conflict in the Arctic, given that the Conservative government was trying to project an image of strength and commitment to defend the country's sovereignty. But this "use it or lose it" rhetoric frustrated and even offended Northerners, particularly Indigenous peoples who had lived in the region since "time immemorial" (and thus resented any intimation that it was not sufficiently "used") and continued to express concerns about their lack of substantive involvement in national and international decision-making. Inuit representatives, for example, suggested that the government agenda prioritized military investments at the expense of environmental protection and improved social and economic conditions in the North. They insisted that "sovereignty begins at home" and that the primary challenges were domestic human security issues, requiring

\footnotetext{
40 Stephen Harper, 'Harper Stands Up for Arctic Sovereignty' address in Ottawa, 22 December 2005 .

41 See, for example, Kathleen Harris, 'Laying claim to Canada's internal waters' Toronto Sun (Toronto 23 February 2007). On Harper's early vision, see Klaus Dodds, 'We are a Northern Country: Stephen Harper and the Canadian Arctic' [2011] 47 (4) Polar Record 371-374.
} 
investments in infrastructure, education, and health care. ${ }^{42}$ Furthermore, the Inuit Circumpolar Council's transnational Circumpolar Inuit Declaration on Sovereignty in the Arctic (2009) emphasized that "the inextricable linkages between issues of sovereignty and sovereign rights in the Arctic and Inuit selfdetermination and other rights require States to accept the presence and role of Inuit as partners in the conduct of international relations in the Arctic." The declaration envisions the Inuit playing an active role in all deliberations on environmental security, sustainable development, militarization, shipping, and socio-economic development. ${ }^{43}$

\section{Canada's Integrated Northern Strategy}

After the Ilulissat Declaration by the Arctic coastal States in May 2008, official Canadian statements began to adopt a more optimistic and less bellicose tone. In March 2009, Minister of Foreign Affairs Lawrence Cannon acknowledged in a speech that geological research and international law (not military clout) would resolve continental shelf and boundary disputes, and he emphasized "strong Canadian leadership in the Arctic ... to facilitate good international governance in the region." 44 These constructive messages were echoed in Canada's Northern Strategy: Our North, Our Heritage, Our Future, released the

42 See, for example, Paul Kaludjak, 'The Inuit are here, use us' Ottawa Citizen (Ottawa 18 July 2007); Mary Simon, 'Does Ottawa's northern focus look backwards?' Nunatsiaq News (11 April 2008); and the perspectives in Inuit Tapiriit Kanatami, Nilliajut: Inuit Perspectives on Security, Patriotism and Sovereignty (Inuit Qaujisarvingat, Ottawa 2013).

43 Inuit Circumpolar Council (ICC), 'A Circumpolar Declaration on Sovereignty in the Arctic' (Ottawa 2009), <https://www.itk.ca/publication/circumpolar-declaration-sovereignty -arctic > accessed 26 October 2016. Inuit representatives have opposed state actions that they feel violate their interests, such as Canada's decision to host a meeting for the five Arctic coastal states in March 2010 without inviting Inuit and First Nations to the discussions, and even critiqued a bilateral Canada-Denmark Arctic defence and security cooperation agreement because they were not involved in negotiating it. As such, indigenous voices add to the complexity (and richness) of the Canadian message projected to the rest of the world.

44 Speaking Notes for the Hon. Lawrence Cannon, Minister of Foreign Affairs, "Canada's Arctic Foreign Policy: The International Dimension of Canada's Northern Strategy," Whitehorse, Yukon, 11 March 2009, reprinted in P. Whitney Lackenbauer and Ryan Dean, Canada's Northern Strategy under Prime Minister Stephen Harper: Speeches and Documents on Sovereignty, Security, and Governance, 2006-15 (Centre for Military, Security and Strategic Studies/Centre on Foreign Policy and Federalism, 2016 Calgary and Waterloo), 77-79. 
following July. It emphasized four main pillars: exercising Canada's Arctic sovereignty, promoting social and economic development, protecting Canada's environmental heritage, and improving and devolving Northern governance. The strategy reinforces a message of partnership: between the federal government and Northern Canadians, and between Canada and its circumpolar neighbours. Although it trumpeted the government's commitment to "putting more boots on the Arctic tundra, more ships in the icy water and a better eyein-the-sky," it also emphasized that Canada's disagreements with its neighbours were "well-managed and pose no sovereignty or defence challenges for Canada." This signaled a rather abrupt change of tone from previous political messaging. 45

Rather than a "use it or lose it" message, Canada's Northern Strategy stressed opportunities for cooperation in the circumpolar world. The strategy cast the United States as an "exceptionally valuable partner in the Arctic" with which Canada has managed its differences responsibly since the Second World War. It also emphasized opportunities for cooperation with Russia and "common interests" with European Arctic states, as well as a shared commitment to international law. Implicitly, this confirmed that bilateral and multilateral engagement is key to stability and security in the region. "We're not going down a road toward confrontation," Cannon emphasized. "Indeed, we're going down a road toward co-operation and collaboration. That is the Canadian way. And that's the way my other colleagues around the table have chosen to go as well." The foreign minister insisted that his government saw the Arctic as an "absolute priority" and that the needs of Northerners would be at the heart of Arctic policy.

The Department of Foreign Affairs released its Statement on Canada's Arctic Foreign Policy in August 2010. ${ }^{46}$ This document reiterated the importance of the Arctic in Canada's national identity and Canada's role as an "Arctic power." The overall message mirrored the broader Northern Strategy, outlining a vision for the Arctic as "a stable, rules-based region with clearly defined boundaries, dynamic economic growth and trade, vibrant Northern communities, and healthy and productive ecosystems." These themes-which bear striking resemblance to The Northern Dimension of Canada's Foreign Policy released in 2000-reinforce how recent strategic messaging from Ottawa

45 Canada, Canada's Northern Strategy: Our North, Our Heritage, Our Future (Department of Indian Affairs and Northern Development, Ottawa 2009).

46 Canada, Statement on Canada's Arctic Foreign Policy (Department of Foreign Affairs and International Trade, 2010, Ottawa). The following paragraphs are derived from this document. 
reflects an approach to circumpolar issues that began under the Liberals but was simply pushed more forcefully by the Conservatives.

The first and foremost pillar of Canada's foreign policy is "the exercise of our sovereignty over the Far North." The "hard security" message has been muted since 2009, and the tone of cooperation with circumpolar neighbours and Northerners has been amplified. Reaffirming that Canada's Arctic sovereignty is longstanding, well-established and based on historic title (rooted, in part, on the presence of Inuit and other Canadians in the region since time immemorial), the statement projects a stable, secure circumpolar world—but one in which Canada will continue to uphold its rights as a sovereign, coastal state. Accordingly, Canada's Arctic Foreign Policy Statement commits Canada to "seek to resolve boundary issues in the Arctic region, in accordance with international law" and to secure its rights to the extended continental shelf. Longstanding disputes respecting the Northwest Passage, Beaufort Sea, and Hans Island are well-managed and pose no acute sovereignty or security concerns to Canada. ${ }^{47}$ Leading Canadian academic experts seem to have reached a similar consensus, with previous proponents of the "sovereignty on thinning ice" school largely abandoning their earlier arguments that Canadian sovereignty will be a casualty of climate change and foreign challenges. Instead, academic narratives anticipating potential conflict now emphasize how other international events (such as Russian aggression in the Ukraine) could "spill over" into the Arctic or how new non-Arctic state and non-state actors might challenge or undermine Canadian sovereignty and security. ${ }^{48}$

47 On 28 November 2012, the Foreign Ministers of Canada and the Kingdom of Denmark announced that they had reached a tentative agreement on where to establish the boundary in the Lincoln Sea. Negotiators are transforming the tentative agreement into a treaty text for ratification by their respective governments.

48 See, for example, Rob Huebert, 'Why Canada, US must resolve their Arctic border disputes,' Globe and Mail (21 October 2014); Huebert, 'How Russia's move into Crimea upended Canada's Arctic Strategy' Globe and Mail (2 April 2014); Huebert, 'Is Canada ready for Russia's hardball approach to the North Pole' Globe and Mail (30 January 2014); Derek Burney and Fen Osler Hampson, 'Arctic alert: Russia is taking aim at the North' Globe and Mail (9 March 2015); Michael Byers, 'The Northwest Passage Dispute Invites Russian Mischief' National Post (28 April 2015); Chris Sorensen, 'The World's First IceBusting Yachts Open the High Arctic' Maclean's (30 December 2015); Scott Borgerson and Michael Byers, 'The Arctic Front in the Battle to Contain Russia' Wall Street Journal (New York 8 March 2016). For a less alarmist view of Russia, see Adam Lajeunesse and Whitney Lackenbauer, 'Canadian Arctic Security: Russia's Not Coming' (ArcticDeeply, 14 April 2016) <https://www.opencanada.org/features/canadian-arctic-security-russias-not-coming > accessed 25 September 2016. 
Other dimensions of the Statement on Canada's Arctic Foreign Policy reflect the interaction between domestic and international agendas in Canada's Northern strategy. Canada's North is home to numerous worldclass mineral deposits, and the country has a long-standing reputation for welcoming foreign investment in its resource sector. Trade and investment in resource development, a primary catalyst for the surge in international interest in the Arctic, are upheld as main priorities given that the mining and energy sectors are key drivers of northern economies and offer significant opportunities for economic and social development. Accordingly, the second pillar, "Promoting Economic and Social Development," promotes the idea that creating a dynamic, sustainable northern economy and improving the social well-being of Northerners is essential to unleashing the true potential of Canada's Northern Territories. The statement emphasizes that Canada is actively promoting Northern economic and social development internationally on three key fronts: 1) taking steps to create the appropriate international conditions for sustainable development; 2) seeking trade and investment opportunities that benefit Northerners and all Canadians; and 3) encouraging a greater understanding of the human dimension of the Arctic.

The third pillar, "Protecting the Arctic Environment," suggests that Canada is taking concrete action to protect and manage the unique and fragile ecosystems and wildlife of the Arctic, which are being affected by global forces. Its "comprehensive approach" to environmental protection, built around the idea of sustainability, seeks to balance the frontier-homeland equation, "ensuring [that] conservation keeps pace with development and that development decisions are based on sound science and careful assessment." ${ }^{\text {49 }}$ Recent domestic initiatives have included cumulative impact monitoring programs, scientific research to support regulatory decision-making related to Northern oil and gas management, remediation of contaminated military and mine sites, the creation of new terrestrial and marine protected areas, and the expanded application of the Arctic Waters Pollution Prevention Act to the full extent of Canada's Exclusive Economic Zone.50 In the international sphere, Canada's official

49 Canada, 'Protecting our Environmental Heritage' (Government of Canada, updated 13 April 2015), <http://www.northernstrategy.gc.ca/env/index-eng.asp> accessed 26 October 2016.

5o Kristin Bartenstein, 'The 'Arctic exception' in the law of the sea convention: a contribution to safer navigation in the northwest passage?' [2011] 42 (1-2) Ocean Development \& International Law $22-52$. Pursuant to article 234 of UNCLOS, on 1 July 2010 Canada also implemented mandatory ship reporting (NORDREG) for vessels destined for Canada's 
environmental actions pursuant to its Northern Strategy are geared towards: 1) promoting an ecosystem-based management approach together with Arctic neighbours and others; 2 ) contributing to and supporting international efforts to address climate change in the Arctic; 3) enhancing efforts on other pressing international issues, including pursuing and strengthening international standards for environmental protection; and 4) strengthening Arctic science, building on the legacy of the International Polar Year (IPY, 2007-08).

Science and technology is considered a cross-cutting theme that underpins all of Canada's Northern Strategy priorities. As a world leader in Arctic science (second only to the United States in terms of scientific publications on the Arctic), ${ }^{51}$ its research extends beyond the academic sector to the private, not-for-profit, and government sectors (including Indigenous researchers and organizations). Official statements tout that Aboriginal peoples and Northerners played a significant role in Canada's planning, coordination, and implementation of its contributions to IPY, and that Canada's investment of $\$ 156$ million was one of the largest by a single country. ${ }^{52}$ The government has committed to significant new infrastructure in support of Northern science, including a new polar icebreaker and remote sensing systems to support northern monitoring activities such as sea ice monitoring for navigation support, vessel detection in support of security and safety, and various environmental monitoring activities including pollution detection and marine wind derivation. As a flagship initiative, Canada is investing \$250-million in building the Canadian High Arctic Research Station (CHARs) - a world-class hub for science and technology, based in Cambridge Bay, Nunavut - that it hopes will attract international scientists to work with Canadians. ${ }^{53}$

The fourth pillar commits to "Improving and Devolving Governance and Empowering the Peoples of the North." Domestically, this involves the ongoing

Arctic waters, replacing the previous voluntary reporting system which had been in place since 1977 .

$5^{1} \quad$ Grégoire Côté and Michelle Picard-Aitken, Arctic Research in Canada: A Bibliometric Analysis (Science-Metrix for Indian and Northern Affairs Canada, Montreal 2009); Canadian Polar Commission, The State of Northern Knowledge in Canada (Canadian Polar Commission, Ottawa 2014).

52 Canada, Government of Canada Program for International Polar Year: Highlights and Achievements (Minister of Aboriginal Affairs and Northern Development, Ottawa 2011).

53 Polar Knowledge Canada, 'Constructing the research station' (Government of Canada, updated 2 June 2016) <https://www.canada.ca/en/polar-knowledge/constructingstation/ index.html > accessed 26 October 2016; Jane George, 'Science, high-tech, guide Nunavut's Canadian High Arctic Research Station' (Nunatsiaq News, 29 October 2015) accessed 26 October 2016. 
negotiation and implementation of land claim and self-government agreements with Northern Indigenous peoples, as well as the negotiation of devolution agreements of federal responsibilities to the territorial governments. In its international dimension, improved governance includes continued support for the Indigenous Permanent Participant organizations of the Arctic Council, and ensuring that Northern governments and Indigenous organizations in Canada have opportunities to actively participate in shaping Canadian policy on Arctic issues. In Canada's view, this high level of engagement with Permanent Participants (as rights-holders ${ }^{54}$ ) and other Northern stakeholders is vital to ensuring that the Arctic Council continues to respond to the regions challenges and opportunities.

The Statement on Canada's Arctic Foreign Policy emphasizes the Arctic Council as the leading intergovernmental forum through which Canada advances its Arctic foreign policy. This reflects its strong contributions to the founding and activities of the Council since 1996, including significant government, Indigenous, and academic expertise, leadership, and resources (both human and financial) to the various working groups and task forces. Accordingly, Canada assumed its second tenure as Chair of the Arctic Council from 2013-15 with great optimism. Canada's vision for the Arctic was again reflected in its overarching theme, "Development for the People of the North," and its three sub-themes: Responsible Arctic Resource Development, Safe Arctic Shipping, and Sustainable Circumpolar Communities. These themes, determined by a government-led public engagement process with northern Canadians, focused on enhancing the capacity of Indigenous Permanent Participants, creating conditions for dynamic and sustainable economic growth, and promoting vibrant communities and healthy ecosystems. ${ }^{55}$ The federal government's appointment of Leona Aglukkaq (the first Inuk to serve as a Canadian Cabinet

54 On the distinction between stakeholders and rightsholders, see Statement by Patricia A.L. Cochran Chair, Arctic Council Indigenous Peoples' Secretariat and Chair, Inuit Circumpolar Council, to the Meeting of Senior Arctic Officials of the Arctic Council, Kautokenio, Norway, (19-20 November 2008), <https://arcticcouncil.longsight.com/bitstream/handle/ 11374/883/ACSAONOo4_11_Statement_IPS_Chair.pdf?sequence=1\&isAllowed=y $>$ accessed 24 November 2016.

55 Canada's Arctic Council Chairmanship, 2013-2015 (Department of Foreign Affairs and International Trade, Ottawa 2013). 
minister) as Canada's Minister and Chair of the Arctic Council reaffirmed a national commitment to Indigenous leadership. Although her appointment elicited criticism from some commentators who questioned her mandate and competency because she was not Canada's foreign minister, others were pleased to see an Arctic Indigenous person serve as chair of the Arctic Council for the first time. ${ }^{56}$

During the course of its chairmanship, Canada committed to eleven priority initiatives: strengthening the Arctic Council; creation of a Circumpolar Business Forum; Arctic marine oil pollution prevention; ${ }^{57}$ guidelines for arctic tourism and cruise ship operations in the Arctic; protecting Arctic traditional ways of life; promoting traditional and local knowledge; addressing short-lived climate pollutants; facilitating adaptation to climate change; promoting mental wellness in Northern circumpolar communities; migratory bird conservation; and enhancing scientific cooperation in the Arctic. All of the Arctic Council states and Permanent Participants supported these initiatives, the first ten of which Canada proposed and the eleventh (on scientific cooperation) coming from the U.S. and Russia. ${ }^{58}$ This agenda invited criticisms from stakeholders who worried that Canada's agenda departed from the Council's traditional emphasis on environmental protection and scientific assessments, instead imposing a parochial Canadian (rather than a circumpolar) vision. "Rather than viewing the Arctic as an increasingly global place, with a legitimate role for non-Arctic actors," political scientist Heather Exner-Pirot suggests, "Aglukkaq prioritized

56 On the debate over Aglukkaq's appointment and the northern consultations, see Heather Exner-Pirot, 'Canada's Arctic Council chairmanship (2013-2015): a post-mortem' (2016) 22 (1) Canadian Foreign Policy Journal 86.

57 Arctic States signed an Agreement on Cooperation on Marine Oil Pollution Preparedness and Response at Kiruna Ministerial Meeting in May 2013, but the Arctic Marine Oil Pollution Prevention initiative was revised in light of American and Norwegian concerns, with the U.s. reticent to support language that implied the negotiation of a new international instrument and Norway reluctant to discuss standards. In the end, the Council developed a Framework Plan for Cooperation on Prevention of Oil Pollution from Petroleum and Maritime Activities in the Marine Areas of the Arctic to promote regulatory cooperation in the petroleum and shipping industries to prevent marine oil pollution, protect the environment and local economies, and safeguard traditional livelihoods and ways of life. Canada, 'Highlights of the Arctic Council Program (2013-15)' updated 4 November 2015 <http://www.international.gc.ca/arctic-arctique/chairman ship-presidence.aspx?lang=eng $>$ accessed 26 October 2016.

$5^{8}$ The Kiruna Declaration (2013) referred to eight of these initiatives, with the two initiatives that were not mentioned (Guidelines for Arctic Tourism and Cruise Ship Operations, and Migratory Bird Conservation) captured in the relevant Working Group sections of the Senior Arctic Officials (SAO) Report to Ministers. 
activities that supported Northerners, especially Canadian Northerners, and more specifically Nunavummiut, and in particular Inuit." ${ }^{25}$

The first sub-theme, Responsible Arctic Resource Development, emphasized the sustainable development of natural resources. Canada's "top priority" along these lines was the creation of a "Circumpolar Business Forum," intended to bring circumpolar business perspectives and advice to the work of the Council. The Arctic Economic Council (AEC) held its first meeting in Iqaluit in September 2014. As an "independent organization that facilitates Arctic business-to-business activities and responsible economic development through the sharing of best practices, technological solutions, standards and other information," the AEC's membership represents a wide range of business interests: "from mining and shipping companies to reindeer herding and Aboriginal Economic Development Corporations." ${ }^{\prime 0}$ Although prematurely criticized for potentially undermining the Arctic Council and the unique status of Permanent Participants, as well as for providing "transnational corporations with preferential access to national governments,"61 the realities of the AEC remain much more modest and aspirational at this stage, offering the prospect of business support to bolster Canada's desire that Arctic communities benefit from the economic boom that is unfolding in the region.

The Safe Arctic Shipping theme built upon previous Council recommendations, such as the landmark Arctic Marine Shipping Assessment (2009), ${ }^{62}$ as well as the ongoing work of multilateral mechanisms like the International

59 Exner-Pirot, 'Canada's Arctic Council chairmanship' 87.

6o Arctic Economic Council, 'Backgrounder' <http://arcticeconomiccouncil.com/aboutus/backgrounder/> accessed 26 October 2016. AEC members decided to focus their efforts on five overarching themes: establishing strong market connections between the Arctic states; encouraging public-private partnerships for infrastructure investments; creating stable and predictable regulatory frameworks; facilitating knowledge and data exchange between industry and academia; and traditional indigenous knowledge, stewardship and a focus on small businesses. Arctic Economic Council, 'Messaging' (Arctic Economic Council, 30 September 2014) <http://arcticeconomiccouncil.com/wp-content/ uploads/2015/o1/AEC-Backgrounder.pdf > accessed 26 October 2016.

61 See Lloyd Axworthy and Mary Simon, 'Is Canada undermining the Arctic Council?' Globe and Mail (4 March 2015). In actual practice, permanent participants have voting privileges within the AEc. See Chris Windeyer, 'The Arctic Economic Council Makes an Entrance' (Arctic Deeply, 4 May 2016) <https://www.newsdeeply.com/arctic/articles/2016/05/04/ the-arctic-economic-council-makes-an-entrance > accessed 24 October 2016. On controversy over the AEC, see also Exner-Pirot, 'Canada's Arctic Council chairmanship' 89-90, 93.

62 Arctic Council, Arctic Marine Shipping Assessment 2009 Report (Protection of the Arctic Marine Environment Working Group, Oslo 2009). 
Maritime Organization (IMO). At the Arctic Council, the Protection of the Arctic Marine Environment (PAME) Working Group developed best practice guidelines for sustainable marine-based tourism and safer cruise-ship operations in the Arctic, encouraging the benefits of tourism for Arctic communities while seeking to mitigate the risks associated with increased activity. ${ }^{63}$ This activity also complemented and encouraged the conclusion and adoption of the International Polar Code, negotiated through the Imo, which Canada had long championed and which is expected to enter into force on 1 January $2017{ }^{64}$ These initiatives reflect Canada's consistent advocacy for the protection of the Arctic environment, and reflect its interests as both a maritime nation and an Arctic coastal state that welcomes navigation in its waters, so long as maritime activities comply with domestic and international rules and regulations.

Work under the third theme, Sustainable Circumpolar Communities, also reinforced the human and environmental dimensions of a changing Arctic. Under Canada's chairmanship, the Sustainable Development Working Group (SDWG) worked with Indigenous communities and health professionals to identify successful approaches to improve mental wellness and resiliency, designed to help Arctic residents (particularly youth) adapt based on solutions that reflect Indigenous cultures and values. ${ }^{65}$ The SDWG also developed recommendations to integrate traditional and local knowledge into its work more consistently (a topic of ongoing debate since the founding of the Council) and facilitated PP-led efforts to enhance their capacity and participation in Council

63 Canada, 'Highlights of the Arctic Council Program'.

64 On the Iмо Polar Code, see David VanderZwaag, "The Iмо and Arctic Marine Environmental Protection: Tangled Currents, Sea of Challenges' in Oran Young, Jong Deog Kim, and Yoon Hyung Kim (eds), The Arctic in World Affairs (Korea Maritime Institute and Honolulu: East West Center, Seoul 2012) 99-128; Jiayu Bai, 'The Imo Polar Code: The Emerging Rules of Arctic Shipping Governance' 2015] 30 (4) International Journal of Marine and Coastal Law 674-699; and Iм0, 'Shipping in polar waters' (International Marine Organization) <http://www.imo.org/en/MediaCentre/HotTopics/polar/Pages/ default.aspx> accessed 25 September 2016. On Canada's role, see Peter Kikkert, 'Promoting national interests and fostering cooperation: Canada and the development of a polar code' (2012) 43Journal of Maritime Law \& Commerce 319.

65 Results of this project were shared at the Circumpolar Mental Wellness Symposium held in Iqaluit in March 2015. See 'Sharing Hope: Circumpolar Perspectives on Promising Practices for Promoting Mental Wellness and Resilience' (2015), <https://arcticcouncil .longsight.com/bitstream/handle/11374/411/ACMMCAog_Iqaluit_2015_SDWG_Sharing Hope_Promoting_Mental_Wellness.pdf?sequence=1\&isAllowed=y> accessed 26 October 2016. 
activities. ${ }^{66}$ With respect to climate change, the Council launched a web-based adaptation portal to facilitate information sharing between Arctic residents, researchers and decision-makers ${ }^{67}$ and, building on the Council's ongoing scientific assessment work, developed an action plan to help reduce short-lived climate pollutants (such as black carbon and methane) that warm the Arctic and harm the air quality and the health of Arctic residents. ${ }^{68}$ Progress in other priority areas, such as the Arctic Migratory Birds Initiative (a longstanding biodiversity project), also acknowledged the importance of enhanced cooperation between Arctic and non-Arctic countries to conserve vulnerable species

66 See Arctic Council, Indigenous Peoples Secretariat, 'Draft Recommendations' (from the PP-led workshop on Traditional Knowledge and the Arctic Council held in Reykjavik in February 2014), <http://arcticpeoplestest.org/traditional-knowledge-workshop/draftrecommendations/> accessed 26 October 2016. The 2015 Iqaluit Declaration notes that the Ministers of the Arctic states "welcome the recommendations on traditional and local knowledge and recognize the importance of using this knowledge in the work of the Council, instruct the Arctic Council to take relevant actions to implement these recommendations, and note with appreciation the work done by the Permanent Participants to develop their own principles for the use of traditional knowledge." Canada, 'Iqaluit Declaration' (Canada, 2015), <http://www.international.gc.ca/arcticarctique/final-declaration-finale.aspx?lang=eng $>$ accessed 24 November 2016. On PP capacity initiatives, see Jim Gam[b]le, 'The Arctic Council Permanent Participants: Capacity \& Support-Past, Present \& Future' in Lassi Heininen, Heather Exner-Pirot, and Joel Plouffe (eds), 2015 Arctic Yearbook: Arctic Governance and Governing, (Northern Research Forum, Akureyri 2015) 385-88.

67 The Arctic Adaptation Exchange project, led by the SDWG, developed an on-line portal that enhances adaptive capacity and fosters the exchange of information/knowledge and the development of best practices by: providing appropriate access to data, knowledge and decision-support tools needed by governments, industry, Arctic indigenous peoples and other residents to manage climate change risks; enabling the sharing of exiting tools and practical adaptation experiences including local and traditional knowledge across the Arctic; and facilitating the development of new practices and tools that support adaptation decision-making(e.g. arctic wide adaptive capacity indices).Canada, the United States, Aleut International Association and Gwich'in Council International collaborated to lead this project. Arctic Council, 'Arctic Adaptation Exchange' <http://arcticadaptation exchange.com/> accessed 29 October 2016.

68 See Arctic Council Secretariat, 'Overview of National Submissions under the Arctic Council Framework for Action on Enhanced Black Carbon and Methane Emissions Reductions' (Arctic Council, 2015) <https://oaarchive.arctic-council.org/handle/11374/1502> accessed 26 October 2016. The Short-Lived Climate Pollutants (SLCPs) initiative was revised to reflect the concerns of Russia, which wanted the focus to focus solely on scientific research. In the end, the Arctic states and PPs reached consensus to proceed with work focusing on black carbon and methane, which included both supporting science and the development of appropriate national activities to reduce emissions of these pollutants. 
and protect traditional Indigenous ways of life. The meat, eggs, and down of migratory birds are important to many Indigenous communities in the Arctic, but most of these species travel to lower latitudes during the winter where they face habitat destruction and pollution. Accordingly, multi-jurisdictional conservation plans, based on rigorous monitoring plans, must reflect the Arctic's connectedness to the rest of the world. ${ }^{69}$

In the end, Canada's chairmanship achieved a mixed success. The official summary report emphasized that it had "worked to support economic prosperity in the region, recognizing that business is essential to support residents and create sustainable communities," and it had "also supported Arctic Indigenous peoples as they continue to adapt to changing social, economic, cultural and environmental conditions." ${ }^{\prime 0}$ While these areas of emphasis served to reorient the Council's work towards human development, ExnerPirot noted "many grumblings about Canada's management and leadership of the chairmanship, with some [stakeholders] expressing that it lacked transparency, decisions were made without sufficient consultation, and emphasis was inevitably placed on issues of Canadian domestic concern." Canada's chairmanship did not produce any landmark assessments, yield any binding treaties, or convince other Arctic Council states that Canada's domestic economic priorities were simply transferrable to the rest of the circumpolar world. While tensions with Russia over external developments in the Ukraine and Syria may have inhibited progress on some initiatives, Exner-Pirot concludes that Canada's chairmanship also reflected the shortcomings of Canada's leadership, particularly its propensity to conflate domestic and international agendas. ${ }^{71}$

\section{$5 \quad$ The New Liberal Government: A New Way Forward?}

On 19 October 2015, Justin Trudeau's Liberal party won the Canadian federal election with a sweeping majority. Although this represented a clear repudiation of Stephen Harper's Conservative government, it should not be misconstrued as an inherent rejection of the 2009 Northern Strategy which, while released under the Conservatives, reflects a longstanding Canadian Arctic agenda built around sovereignty, sustainable development, environmental

69 Conservation of Arctic Flora and Fauna (CAFF) Working Group, 'Arctic Migratory Birds Initiative (АМВI)' <http://www.caff.is/arctic-migratory-birds-initiative-ambi> accessed 17 October 2016.

70 Canada, 'Highlights of the Arctic Council Program'.

71 Exner-Pirot, “Canada's Arctic Council chairmanship," 90-94. 
protection, and governance. The change in government, however, is likely to bring a change in tone and emphasis to highlight a political departure-even if the main substantive elements of Canada's Arctic policy are likely to remain intact. Similar to previous administrations, it is likely that Trudeau's Arctic agenda will continue to focus on domestic issues-particularly those related to the health and resiliency of Indigenous communities. Internationally, this agenda is complemented by a renewed commitment to global climate change mitigation, a "return" to multilateralism and a foreign policy rooted in "responsible conviction," and a more constructive relationship with the United States. ${ }^{72}$

Respect for and reconciliation with Indigenous peoples lies at the heart of the Liberal agenda. "No relationship is more important to me and to Canada than the one with Indigenous Peoples," Trudeau highlighted in his mandate letter to each of his Cabinet ministers. "It is time for a renewed, nation-tonation relationship with Indigenous Peoples, based on recognition of rights, respect, co-operation, and partnership." ${ }^{73}$ Accordingly, Canada will place the highest priority on ensuring that its activities in the Arctic (both domestic and international) acknowledge, protect and promote Indigenous peoples' rightsand, by extension, will insist that other Arctic stakeholders do the same. ${ }^{74}$ In May 2016, Canada officially lifted the qualifications to its endorsement of the United Nations Declaration on the Rights of Indigenous Peoples (UNDRIP),

72 See, for example, Matthew Bondy, 'Justin Trudeau is Putting the 'Liberal' Back in 'Canadian Foreign Policy" (2015) Foreign Policy <http://foreignpolicy.com/2015/10/21/justin -trudeau-liberal-canadian-foreign-policy-syria-climate-change/> accessed 17 October 2016; Lee Berthiaume, 'A return to multilateralism' (2015) National Post; and Stéphane Dion, 'On 'responsible conviction' and Liberal foreign policy' (2016) Maclean's <http:// www.macleans.ca/politics/ottawa/stephane-dion-how-ethics-inspires-liberal-foreignpolicy/> accessed 17 October 2016. On the new government's main priorities and their relationship to the North, see Thomas Axworthy, 'In the North, Justin Trudeau can accomplish great things' Toronto Star (Toronto, 6 March 2016).

73 Prime Minister of Canada, 'Ministerial Mandate Letters' <http://pm.gc.ca/eng/ministerialmandate-letter> (Justin Trudeau, Prime Minister of Canada) accessed 29 October 2016.

74 The Statement on Canada's Arctic Foreign Policy adopts the phrase Canadian "Aboriginal People," thus emphasizing individuals living in the North, rather than the plural "peoples" connoting group rights. This reflects a longstanding debate in Canada about Indigenous rights to self-determination under international law. According to some strands of international law, and especially Article 1 of the Covenant, the word "peoples" opens up the prospect of unqualified acceptance of self-determination. See, for example, Andrew F. Cooper, Tests of Global Governance: Canadian diplomacy and United Nations world conferences (Tokyo: United Nations University Press 2004) 122-51. The Trudeau Government, however, seems fully prepared to acknowledge Aboriginal peoples as collective entities as well. 
which the Conservatives had registered over the requirement for "free, prior and informed consent" from Indigenous peoples on issues that affected them. While disavowing that this new position gives Indigenous groups a "veto" over development projects, ${ }^{75}$ Canada's unqualified support of UNDRIP affirms a strong commitment to welcome "Indigenous peoples into the co-production of policy and joint priority-setting" within the Canadian political community. ${ }^{76}$

Prime Minister Trudeau has also declared that Canada "is back" when it comes to joining global efforts to mitigate climate change. ${ }^{77}$ While the Harper government emphasized climate change adaptation measures in its Arctic agenda, the Liberals chastised their predecessors' alleged "refusal to take meaningful action on climate change," their lack of funding for science and their "muzzling" of government scientists, and their prioritization of economic growth over environmental protection. ${ }^{78}$ In signing the Paris Agreement on climate change, Canada has signalled its commitment to shift course, reduce greenhouse-gas emissions in concert with the international community, and promote a clean-energy future. ${ }^{79}$ Along these lines, the U.S.-Canada Joint Statement of March 2016 articulated "a common vision of a prosperous and sustainable North American economy, and the opportunities afforded by advancing clean growth." Both Trudeau and Obama cited the Paris Agreement as a pivotal moment and committed to reduce methane emissions from the oil and gas sector, as well as advancing climate change action globally. They also

75 Gloria Galloway, 'Canada drops opposition to UN indigenous rights declaration,' Globe and Mail (9 May 2016);

76 Ken Coates and Bill Favel, 'Embrace of Und RIP Can Bring Aboriginal Canada and Ottawa Closer Together' (iPolitics, 19 May 2016) <http://www.macdonaldlaurier.ca/embrace-of -undrip-can-bring-aboriginal-canada-and-ottawa-closer-together-ken-coates-and -blaine-favel-for-ipolitics/> accessed 29 October 2016.

77 Jason Fekete, 'Justin Trudeau says Canada 'is back at climate-change meeting' National Post (30 November 2015).

78 Liberal Party of Canada, 'A New Plan for Canada's Environment and Economy' (Liberal, August 2015) <https://www.liberal.ca/files/2015/o8/A-new-plan-for-Canadasenvironment-and-economy.pdf> accessed 29 October 2016. On the muzzling of government scientists, see for example Verlyn Klinkenborg, 'Silencing Scientists' New York Times (New York, 21 September 2013); Jonathon Gatehouse, 'When Science Goes Silent' Maclean's (3 May 2013); Margaret Munro, 'Unmuzzling government scientists is just the first step' Globe and Mail, 26 October 2015; and Mark Hume, "Federal scientists eager to share their research now that muzzles are off," Globe and Mail (Toronto, 8 November 2015).

79 Alexa Panetta, 'Trudeau on climate targets: 'Canada's efforts will not cease' (2016) Maclean's <http://www.macleans.ca/politics/ottawa/trudeau-on-climate-targets-canadas -efforts-will-not-cease/> accessed 17 October 2016. 
"reaffirm their commitment to working together to strengthen North American energy security, phase out fossil fuel subsidies, accelerate clean energy development to address climate change and to foster sustainable energy development and economic growth." Both countries also promise to "continue to respect and promote the rights of Indigenous peoples in all climate change decision making." 80

Given Canada's longstanding position that its sovereignty in the Arctic is well-established, there is unlikely to be any reversing of its basic stance on the rights and roles of Arctic states in regional governance. With Prime Minister Trudeau having criticized his predecessor for allegedly politicizing the scientifically-informed legal process to delineate the outer limits of Canada's continental shelf in the Arctic, Canada is likely to emphasize openness, transparency, the rule of law, and science-based decision-making as it navigates the process established by article 76 of UNCLOS for claims to extended continental shelves. ${ }^{81}$ Similarly, the Liberal government is unlikely to succumb to alarmist narratives suggesting that military threats warrant a deviation from our established approach to managing outstanding sovereignty and status of water disputes. ${ }^{82}$ While the new government is more likely to emphasize constructive diplomacy rather than to adopt militant rhetoric on Arctic sovereignty issues, it is unlikely to adopt the de-militarization or nuclear-weapons free zone proposals promoted by a small number of left wing groups and

80 Prime Minister of Canada, 'U.S.-Canada Joint Statement on Climate, Energy, and Arctic Leadership' (Justin Trudeau, Prime Minister of Canada, 10 March 2016) <http://pm.gc.ca/ eng/news/2016/03/10/us-canada-joint-statement-climate-energy-and-arctic-leadership> accessed 17 October 2016.

81 After PM Harper "ordered a rewrite of Canada's international claim for Arctic seabed rights to include the North Pole" in December 2013, Trudeau (as Liberal leader) noted: "I am going to defer to scientists. There has been an awful lot of work done over the past years, and even decades, on mapping out the undersea floor of the North Pole to align with the United Nations regulations.... And I don't know that it is a place where we need necessarily to have political interference. I trust our scientists and oceanographers in terms of how we're mapping it." Steven Chase, 'Turf war with Russia looms over Ottawa's claim to Arctic seabed' Globe and Mail (Toronto: 5 December 2013).

82 See, for example, Scott Michael Byers, 'Arctic Front in the Battle to Contain Russia' (2016) The Wall Street Journal <http://www.wsj.com/articles/the-arctic-front-in-the-battle-to -contain-russia-1457478393> accessed 17 October 2016, and Levon Sevunts, 'Canada's defence review and the Arctic' (Radio Canada International, 8 April 2016) <http://www .rcinet.ca/en/2016/04/08/canadas-defence-review-and-the-arctic/> accessed 17 October 2016. 
commentators. ${ }^{83}$ Instead, the Liberals have promised to maintain current National Defence spending levels, with "a renewed focus on surveillance and control of Canadian territory and approaches, particularly our Arctic regions, and will increase the size of the Canadian Rangers." ${ }^{84}$ This continuity does not promote a "militarization" of the Arctic agenda, but simply represents a modest investment in appropriate defensive capabilities that help to deter wouldbe adversaries from attacking North America and, in a direct Arctic context, to support unconventional security and safety missions such as law enforcement and responding to natural or humanitarian disasters. ${ }^{85}$

The Trudeau government is emphasizing international cooperation in line with a more "nuanced" foreign policy. Building on Trudeau's promise that Canada would have a more "compassionate and constructive voice in the world" under the Liberals after a decade of Conservative rule, in November 2015 newly-appointed Minister of Global Affairs Stéphane Dion called for renewed "engagement" with Russia, despite Canada's ongoing displeasure with Russian expansionism and aggression in the Ukraine. While the Harper Conservatives had suspended almost all bilateral contact with Russia after the latter invaded Crimea in March 2014, Dion stressed that this extreme stand deviated from the actions of the us and other G-7 partners. "We also need to think about our

83 See, for example, Ernie Regehr, 'A Nuclear-Weapon-Free Zone and Cooperative Security in the Arctic' (Simons Foundation, 14 October 2014) <http://www.thesimonsfoundation .ca/highlights/nuclear-weapon-free-zone-and-cooperative-security-arctic $>$ accessed 17 October 2016; Thomas Axworthy, 'A Proposal for an Arctic Nuclear Weapon-Free Zone' (2012) Yearbook of Polar Law 4 (1) 87-139; and Michael D. Wallace and Steven Staples, Ridding the Arctic of Nuclear Weapons: A Task Long Overdue (Rideau Institute, Ottawa 2010).

84 In highlighting the need for "an agile, responsive, and well-equipped military force that can effectively defend Canada and North America," and by mentioning the Arctic in particular, there is no indication that Arctic defence, security, and safety will be downgraded in importance. Instead, the Liberal party promised to make investments in the Royal Canadian Navy a "top priority," including completing the six Arctic and offshore patrol ships (AOPS) announced by the Conservatives and the construction of more icebreakers (presumably for the Canadian Coast Guard). Liberal Party of Canada, 'Defence Platform' (Liberal, 2015) <https://www.liberal.ca/realchange/royal-canadian-navy/> accessed 24 October 2016.

85 P. Whitney Lackenbauer and Adam Lajeunesse, 'The Canadian Armed Forces in the Arctic: Building Appropriate Capabilities' (2016) 16 (4) Journal of Military and Strategic Studies 7-66. Defence is defined as military actions taken to deter or defeat enemy state actors to protect Canada's North. Security is defined as precautions taken to guard against crime, attack, sabotage or espionage by criminal or non-state actors. Safety is defined as the actions taken to protect life and limb or to mitigate damages to critical infrastructure and government assets from force majeure events. See Canadian Forces Northern Employment Support Plan, November 2012. 
national interests because Russia is our neighbour in the Arctic," the minister explained. ${ }^{86}$ While this revised stance provoked debate amongst Canadian commentators, some of whom worried that this would send the wrong signals to an increasingly assertive Putin already "pivoting" towards the Arctic as a "strategic frontier," 87 the intention to continue cooperation on areas of common ground in Arctic affairs is an eminently sensible one. ${ }^{88}$

While it is premature to determine whether the Trudeau government's policy priorities really "converge in Canada's North," thus investing the region with high political saliency in the country as a whole, ${ }^{89}$ the prominent place of the Arctic in the Trudeau-Obama joint statement of March 2016 points in this direction. Emphasizing Indigenous rights and knowledge, as well as "natural marine, land and air migrations that know no borders," the statement conceptualizes the Arctic as "the frontline of climate change" and articulates four main objectives:

86 Lee Berthiaume, 'Canada ready to re-engage with Russia, Iran, despite differences, Dion says' Ottawa Citizen (Ottawa, 11 November 2015). During the election campaign in October 2015, Trudeau had told reporters that, if he became prime minister, he would "tell off" Putin "directly to his face" after accusing the Russian leader of "being dangerous" in eastern Europe, "irresponsible and harmful" in the Middle East, and "unduly provocative" in the Arctic. Canadian Press, "Justin Trudeau would tell off 'bully' Vladimir Putin 'directly to his face' if he becomes prime minister," National Post, 13 October 2015.

87 In January 2016, Dion reiterated that Canada hoped to resume dialogue with Russia, despite that country's military aggression in the Ukraine, and cited the Arctic as a region where Canada would benefit from re-engagement with its circumpolar neighbour. Scott Borgerson and Michael Byers, 'The Arctic Front in the Battle to Contain Russia' Wall Street Journal (New York, 8 March 2016). See also Matthew Fisher, 'Allies wait for great defence commitment from Canada while Russia militarizes the Arctic' National Post (4 February 2016) <http://news.nationalpost.com/news/canada/matthew-fisher-allieswait-for-greater-defence-commitment-from-canada-while-russia-militarizes-arctic $>$ accessed 24 October 2016; Eva Salinas \& Hannah Hoag [in conversation with Rob Huebert and Heather Exner-Pirot], 'Canada Wants to Reopen Dialogue with Russia' (Arctic Deeply, 17 February 2016) <https://www.newsdeeply.com/arctic/articles/2016/02/17/canadawants-to-reopen-dialogue-with-russia > accessed 24 October 2016.

88 Kari Roberts, 'Why Russia will Play by the Rules in the Arctic' (2015) Canadian Foreign Policy Journal 21 (2) 112-128; and Adam Lajeunesse and Whitney Lackenbauer, 'Canadian Arctic Security: Russia's Not Coming' (OpenCanada, 19 April 2016) <https://www .opencanada.org/features/canadian-arctic-security-russias-not-coming/> accessed 24 October 2016.

89 Thomas Axworthy, 'In the North, Justin Trudeau can accomplish great things' Toronto Star (Toronto, 6 March 2016). 
1) Conserving Arctic biodiversity through science-based decision making by achieving national goals for land and marine protected areas, and working "directly with Indigenous partners, state, territorial and provincial governments" to set "a new, ambitious conservation goal for the Arctic based on the best available climate science and knowledge, Indigenous and non-Indigenous alike.

2) Collaborating with "Indigenous and Arctic governments, leaders, and communities to more broadly and respectfully" incorporate Indigenous science and traditional knowledge into decision-making

3) Building a sustainable Arctic economy based on scientific evidence, with commercial activities occurring "only when the highest safety and environmental standards are met, including national and global climate and environmental goals, and Indigenous rights and agreements." Subpriorities include:

a. establish low impact shipping corridors and consistent policies for ship operations, taking into account important ecological and cultural areas, vessel traffic patterns, Indigenous and Northern Arctic input, and increased coast guard cooperation of our Coast Guards

b. seek a binding international agreement to prevent the opening of unregulated fisheries in the Central Arctic Ocean, building "on a precautionary, science-based principle to commercial fishing that both countries have put in place in their Arctic waters"

c. ensure that oil and gas development and exploration activities "align with science-based standards between the two nations that ensure appropriate preparation for operating in Arctic conditions, including robust and effective well control and emergency response measures"

4) Supporting strong Arctic communities by "defining new approaches and exchanging best practices to strengthen the resilience of Arctic communities and continuing to support the well-being of Arctic residents, in particular respecting the rights and territory of Indigenous peoples." This objective stresses that "all Indigenous Peoples in the Arctic are vital to strengthening and supporting U.S. and Canadian sovereignty claims," and both countries "commit to working in partnership to implement land claims agreements to realize the social, cultural and economic potential of all Indigenous and Northern communities." Priority areas include "innovative renewable energy and efficiency alternatives to diesel"; community climate change adaptation; "innovative options for housing and infrastructure"; and "greater action to address the serious challenges of 
mental wellness, education, Indigenous language, and skill development, particularly among Indigenous youth." 90

Indigenous and environmental organizations in Canada applauded the statement, with national Inuit leader Natan Obed stating that "the final language in this document really spoke to Inuit" and heralding it "a tremendous breakthrough for Indigenous people who live in the Arctic."91

\section{$6 \quad$ Bringing the EU and Canadian Strategies into Dialogue}

The evolution of the European Union's Arctic policy has been the subject of numerous publications ${ }^{92}$ and is dealt with extensively in other chapters in this book. Accordingly, our intention is not to provide yet another summary but rather to use the most recent articulation of European Union policy for the Arctic, released on 27 April 2016 by the Commission and the High Representative for Foreign Affairs and Security Policy as a "Joint Communication to the European Parliament and the Council," as a way to juxtapose EU and Canadian

90 'U.S.-Canada Joint Statement on Climate, Energy, and Arctic Leadership' (Office of the Prime Minister of Canada, 1o March 2016) <http://www.pm.gc.ca/eng/news/2016/o3/10/ us-canada-joint-statement-climate-energy-and-arctic-leadership\#sthash.XjRoT2 77 .dpuf $>$ accessed 24 October 2016.

91 Sima Sahar Zerehi, 'Trudeau-Obama shared Arctic leadership model a hit with Inuit and environmental groups' ( north/trudeau-obama-washington-visit-arctic-promises-1.3486076> accessed 24 October 2016.

92 Important overviews include Adele Airoldi, The European Union and the Arctic: policies and actions (Nordic Council of Ministers, Copenhagen 2008); Adele Airoldi, European Union and the Arctic: Main Developments July 2008-July 2010 (Nordic Council of Ministers, Copenhagen 2010); Adele Airoldi, The European Union and the Arctic: Developments and Perspectives, 2010-2014 (Nordic Council of Ministers, Copenhagen 2014); Steffen Weber and Iulian Romanyshyn, 'Breaking the ice: the European Union and the Arctic' (2011) 66 (4) International Journal 849-860; Kristine Offerdal, 'The EU in the Arctic: in pursuit of legitimacy and influence' (2011) 66 (4) International Journal 861-877; Timo Koivurova, Kai Kokko, Sebastien Duyck, Nikolas Sellheim, and Adam Stepien, 'The present and future competence of the European Union in the Arctic' (2012) 48 (4) Polar Record 361-371; Njord Wegge, 'The EU and the Arctic: European foreign policy in the making' (2012) 3 (1) Arctic Review on Law and Politics 6-28; Andreas Østhagen, 'The European Union-An Arctic Actor?' (2013) 15 (2) Journal of Military and Strategic Studies 71-92; and Adam Stępień, 'Internal Contradictions and External Anxieties: One 'Coherent' Arctic Policy for the European Union?' (2015) 7 (1) Yearbook of Polar Law 249-289. 
policy priorities. Bearing the title "An integrated European Union policy for the Arctic," the EU document proposes three priority areas:

1) Climate Change and Safeguarding the Arctic Environment;

2) Sustainable Development in and around the Arctic; and

3) International Cooperation on Arctic Issues.

An admonition immediately follows this list of priority issues that the "EU should attach particular importance to research, science and innovation which will play a key role across the three priority areas. ${ }^{\prime 93}$ At first glance, these areas resemble the main pillars of Canada's Northern Strategy and Arctic Foreign Policy (described above).

The introductions to both the Canadian and EU strategies acknowledge the significance and complexity of the changes occurring in the Arctic, with particular attention to climate change. Canada's Northern Strategy stresses that the "North is undergoing rapid changes, from the impacts of climate change to the growth of Northern and Aboriginal governments and institutions," and observes that "domestic and international interest in the Arctic region is rising." The introductory paragraphs of the EU Policy also emphasize that the Arctic is acquiring "a higher profile in international relations", concluding that "[w] hile the changes affecting the Arctic present opportunities for local communities, they also have the potential to increase tensions in the region." ${ }^{94}$ As discussed, these dynamics make sovereignty Canada's "first and foremost" priority in Arctic policy. In the case of the EU, the primary policy driver is climate change.

In terms of sovereignty and sovereign rights in the Arctic Ocean, Canada maintains that an established international legal framework is in place and will govern the resolution of maritime boundary disputes and the extended continental shelf. ${ }^{95}$ Indeed, each of the five coastal States bordering the Arctic Ocean reiterated their commitment to the legal framework defined by the UN Law of the Sea Convention and to the peaceful settlement of any disputes in

93 European Commission and The High Representative, 'An integrated European Union policy for the Arctic', Joint Communication, JorN (2016) 21 final, 4.

94 JOIN (2016) 21, 4.

95 With regards to Hans Island, Canada's only outstanding territorial dispute in the Arctic, the Joint Statement adopted by Canada and Denmark in September 2005 has proven extremely successful in managing the dispute. This statement provided that both parties, without prejudice to their respective legal claims, would inform each other of activities related to Hans Island. Furthermore, all contact by either side with Hans Island would be carried out in a low key and restrained manner. 
2008. Although a controversial resolution of the European Parliament in October 2008 called for a new Arctic legal governance regime based upon the Antarctic Treaty (based on the misguided assumption that the region was devoid of governance), subsequent statements by the European Commission have been more sober in recognizing that "an extensive international legal framework is already in place that applies to the Arctic." ${ }^{\prime 6}$ The $2016 \mathrm{EU}$ Arctic policy similarly recognizes that the UNCLOS "provides a framework for managing the Arctic Ocean, including the peaceful settlement of disputes."97 Thus, while the current regime leaves some difficult questions unanswered-for instance, the resolution of overlapping ECS claims or the true nature of the Commission on the Limits of the Continental Shelf's recommendations regarding individual claims ${ }^{98}$ - the existing legal framework ensures that Canada, as an Arctic coastal state, will be an equal party in any future negotiations and settlement.

The principal perceived "threat" to Canada's sovereignty in the Arctic stems from outside opposition to its legal position with respect to the Northwest Passage. Successive Canadian governments have declared that all of the waters within Canada's Arctic archipelago constitute Canadian historic internal waters over which Canada exercises full sovereignty. This assertion of sovereignty necessarily includes the right to govern and control access to the various routes between Canada's archipelagic islands. Washington, on the other hand, has consistently maintained that the Northwest Passage is an international strait through which the ships and aircraft of all nations enjoy a right of transit passage..${ }^{99}$ Other States have also protested Canada's governance measures

96 See, for example, Communication from the Commission to the European Parliament and the Council, 'The European Union and the Arctic Region' сом (2008) 763 final, 9-10 $<$ http://eeas.europa.eu/arctic_region/docs/com_08_763_en.pdf> accessed 29 October 2016.

97 JOIN (2016) 21, 14.

98 On these themes, see Ted McDorman, 'The Role of the Commission on the Limits of the Continental Shelf: A Technical Boday in a Political World' (2002) 17 (3) International Journal of Marine and Coastal Law 301-324; Annick de Marffy Mantuano, 'La fixation des dernières limites maritimes: Le rôle de la Commission des Limites du Plateau Continental' in Daniel-Heywood Anderson et al. (eds), La Mer et son Droit: Mélanges offerts à Laurent Lucchini et Jean Pierre Quénedec (Pedone, Paris 2003) 416; Alex G. Oude Elferink, 'Causes, Consequences and Solutions Relating to the Absence of Final and Binding Outer Limits of the Continental Sheld', Robert Volterra, 'Problems Arising from Submissions by States to the CLCS in relation to Disputed Areas: A Selective Survey of State Practice to Date' and Bjorn Kunoy, 'Legal Problems Relating to Differences Arising between Recommendations of the CLCs and the Submission of Particular States' - all three in Clive R. Symmons (ed), Selected Contemporary Issues in the Law of the Sea (Martinus Nijhoff Publishers, Leiden 2011) at 253, 273 and 305 respectively.

99 See The White House, Section III "Policy", sub-section B 'National Security and Homeland Security Interests in the Arctic' at paragraph 5, January 9, 2009: “The Northwest Passage is 
in the past, ${ }^{100}$ and a 2008 Communication of the European Community and a 2014 European Parliament Resolution emphasized freedom of navigation in the newly-opened Arctic routes. ${ }^{101}$ Furthermore, Germany's Arctic policy guidelines released in September 2013 announced that the country was "campaigning for freedom of navigation in the Arctic Ocean (Northeast, Northwest and Transpolar Passages) in accordance with high safety and environmental standards."102 Given Canada's understandable sensitivities with respect to its sovereignty, these challenges to its legal position are bound to elicit concern and generate political friction.

The 2016 EU Arctic policy for the Arctic does not wade into the Northwest Passage controversy, which bodes well for bilateral relations with Canada. Instead, it emphasizes the need for safe and secure maritime activities - a shared priority with Canada. "In view of increasing vessel traffic in the Arctic, including some carrying flags from EU Member States," it asserts, "the EU should contribute to enhance the safety of navigation in the Arctic through

a strait used for international navigation, and the Northern Sea Route include straits used for international navigation; the regime of transit passage applies to passage through those straits." See also President Obama's 'National Strategy for the Arctic Region' of May 2013: "Accession to the Convention would protect U.S. rights, freedoms, and uses of the sea and airspace throughout the Arctic region, and strengthen our arguments for freedom of navigation and overflight through the Northwest Passage and the Northern Sea Route."

100 For example, in 1978, a Canadian official acknowledged that a "drawer full of protests" had been received following the adoption of Canada's 1970 Arctic Waters Pollution Prevention Act. See Ted McDorman, 'The New Definition of 'Canada Lands' and the Determination of the Outer Limit of the Continental Shelf' (1983) 14Journal of Maritime Law and Commerce 215 .

101 Reference can be made to the 2008 Communication of the European Communities to the European Parliament and the Council, "The European Union and the Arctic Region" in which Member States and the Community were exhorted to "defend the freedom of navigation and the right of innocent passage in the newly opened routes and areas." This call was repeated in paragraph 48 of the recent "European Parliament Resolution of 12 March 2014 on the EU Strategy of the Arctic", which also calls on "the states in the [Arctic] region to ensure that any current transport routes - and those that may emerge in the futureare open to international shipping and to refrain from introducing any arbitrary unilateral obstacles, be they financial or administrative, that could hinder shipping in the Arctic, other than internationally agreed measures aimed at increasing security or protection of the environment.

102 Auswärtiges Amt, 'Guidelines of the Germany Arctic Policy-Assume Responsibility, Seize Opportunities' (Auswärtiges Amt, September 2013) <http://www.bmel.de/SharedDocs/ Downloads/EN/International/Leitlinien-Arktispolitik.pdf?_blob=publicationFile> accessed 24 October 2016. 
innovative technologies and the development of tools for the monitoring of spatial and temporal developments of the increasing maritime activities in the Arctic." 103 The Eu policy only references the "North East Passage" (more commonly referred to as the Northern Sea Route $)^{104}$ and, even then, only does so with regards to the stated objective of creating a "network for the Arctic and the Atlantic" to cope with any maritime security threats that might result from increasing activity within the Passage. Emphasis is placed on ensuring the effective implementation of the Polar Code and enhancing search and rescue capabilities-all critical issues for Canada. Accordingly, as long as Canada's position on the status of the waters of the NWP is left uncontested, ${ }^{105}$ the European emphasis on enhancing stewardship of the Arctic waters falls into perfect alignment with Canadian priorities under its sovereignty, environmental, and development pillars.

While the $2016 \mathrm{EU}$ Arctic policy is respectful of the sovereignty and primary role of the Arctic States in tackling the issues affecting the Arctic region, ${ }^{106}$ it stresses that climate change, the preservation of biodiversity, and the viability of ecosystems in the Arctic are global challenges best addressed through regional or multilateral cooperation. Acknowledging the particularly acute impacts of climate change in the region, the EU Joint Communication also emphasizes the critical role that the Arctic plays as a regulator for global climate and as a sink for long-range pollution. In light of this critical link between the Arctic and global efforts to combat climate change, the EU policy statement declares that the "EU has a duty to protect the Arctic environment and

103 JOIN (2016) 21, 12, under the heading "Safe and secure maritime activities." Emphasis in the original.

104 As regards shipping activities in Russian Arctic waters, the Northern Sea Route [NSR] is the national maritime transportation route. As Willy Østreng explains, according to "legal regulations in Russia, the NSR stretches from Novaya Zemlya in the west ... to the Bering Strait in the east ... The establishment of the NSR as separate part of the Northeast Passage was decided by the Council of Peoples Commissars of the UssR on 17 December 1932, which was the beginning of the NSR as an administered, legal entity under full Soviet jurisdiction and control." Footnotes omitted, emphasis added. Willy Østreng, 'The Northeast Passage and Northern Sea Route' (ARCTIS, 2010) <http://www.arctis-search .com/The+Northeast+Passage+and+Northern+Sea+Route+2> accessed 24 October 2016.

105 A willingness to "agree to disagree" on intractable issues related to the legal status of the Northwest Passage, as Canada has successfully implemented in its bilateral relationship with the United States, may offer the EU a path to avoid alienating Canadian stakeholders and rights-holders.

106 This important acknowledgment appears in the second paragraph of the seventeen-page document. 
strengthen ecosystem resilience."107 Given the Trudeau government's strong support for multilateral efforts to mitigate climate change and its recognition that the Arctic environment cannot be protected simply through domestic or regional action, both the $\mathrm{EU}$ and Canada should consider the Arctic as a propitious opportunity for joint leadership.

At the heart of both the Canadian and EU Arctic strategies is a commitment to protect the environment and promote the economic development of the region. It remains to be seen, however, whether the interpretation or relative weight given to these dimensions complicates Canada-EU Arctic relations. These issues intersect most clearly in the case of energy. Canada is a major producer of oil and gas (although derided in some European circles as a generator of "dirty oil" from its oil sands), and its Arctic region-although the site of minimal exploration and development activity at present - could become a significant contributor to global energy supply in the long term as technology, equipment, and expertise advance and melting sea ice improves accessibility. While resource development can generate economic growth and opportunities for Northern peoples, Canada also recognizes that it increased risks of oil spills from offshore oil and gas operations and from ships and applies amongst the highest safety and environmental regulatory standards to oil and gas production in the world. ${ }^{108}$ For its part, the European Commission also acknowledges that "Arctic resources could contribute to enhancing the EU's security of supply concerning energy and raw materials in general," 109 and seeks to promote the "highest standards of major accident prevention and environmental control" over oil and gas activities in the region." The recent policy statement also encourages the $\mathrm{EU}$ "to share regulatory and technological best practice with international partners to support the safety and preservation of the environment in the region." 110 Unless the EU decides to adopt an anti-development stance on Arctic oil and gas on environmentalist grounds, their stance on strong regulation of shipping, exploration, and extraction activities is likely to resonate

107 JOIN (2016) 21, 12. Emphasis in original but added for the word "duty."

108 Estimates indicate that over one-third of Canada's remaining total of recoverable conventional sources of oil and natural gas is found in its on- and offshore Arctic region, including $35 \%$ of remaining conventional light crude oil (almost 11.9 billion barrels) and $38 \%$ of conventional natural gas (146.7 trillion cubic feet (Tcf)). Canada, Northern Oil and Gas Annual Report 2015 (Ottawa: Indigenous and Northern Affairs Canada, 2015). There is currently no drilling in Canada's Arctic offshore, although there are an estimated 200 million barrels of oil in the Amauligak field in the shallow waters of the Beaufort Sea and an estimated 240 million barrels of potentially recoverable oil in the Paktoa discovery well.

$109 \operatorname{COM~(2008)~} 763$.

110 JOIN (2016) 21, 8. 
with Canadian interests at the Arctic Council and other multilateral bodies. So too is the shared recognition of the importance of laying the groundwork for future energy security through investments in innovative technologies to support greater energy efficiencies and renewable energy solutions suited to extreme Arctic conditions. ${ }^{111}$

The JOIN (2016) 21 highlights that "close links between research, science and technology, while taking account of traditional knowledge, will ... ensure that development is taken forward in a sustainable way."112 Both Canada and the EU strategies place tremendous weight on the importance of science-based decision making, reaffirming that Arctic research represents a key area of collaboration and cooperation. Science "can be used as a catalyst to support a common understanding," the EU policy suggests, "enabling jointly agreed solutions to be reached and foster peaceful cooperation." 113 Accordingly, as "a major contributor to Arctic research," the Eu's fundamental response to addressing climate change impacts in the Arctic is to maintain and even intensify its research efforts. ${ }^{114}$ This fits with Canada's Northern Strategy priorities, and existing mechanisms already make Canada and Europe longstanding partners in science and technology. For example, the Canada-Eu Science and Technology Cooperation Agreement (1996, amended in 1998) facilitates scientific cooperation by enabling reciprocal access to programs, ${ }^{115}$ and the EU, Canada and the us signed the Galway Statement on research cooperation that led to the establishment of the Transatlantic Ocean (and Arctic) Research Alliance in May 2013.116 Given Canada's aspirations to make the Canadian High Arctic

111 JOIN (2016) 21, 9-10; "U.S.-Canada Joint Statement on Climate, Energy, and Arctic Leadership."

$112 \operatorname{JOIN}(2016) 21,10$.

113 JOIN $(2016) 21,13$.

114 JOIN (2016) 21, 5. Emphasis in original. The Joint Communication contains a wealth of information on EU funding of Arctic research and ongoing Polar/Arctic programmes and initiatives. Reference is made to the EUR 40 million already committed under the 20162017 work programme for Arctic related research and a further commitment is made to maintain current funding levels (around EUR 200 million in the past decade) under the Horizon 2020 programme (2014-2020). Funding for research and innovation activities is also to be provided by the European Structural and Investment Funds (ESIF), a central plank of the Eu's Arctic research efforts.

115 A Joint Science and Technology Cooperation Committee (JSTCC) established under the Agreement meets regularly to identify collaborative activities, tools and initiatives that facilitate international collaboration and to set strategic directions.

116 Under this Alliance, the ERA-CanII project (funded by the European Commission, the Government of Canada and coordinated by the Canadian Foundation for Innovation) 
Research Station a world-class hub for scientific research by experts from around the world, it is highly likely that partnerships between Canadian and European scientists seeking "transnational access to research infrastructure and open data resources"117 will be enhanced.

As a prime example of convergence, both Canada and the EU favour similar approaches for the effective protection of the Arctic's marine biodiversity and ecosystems. ${ }^{118}$ The $2016 \mathrm{EU}$ policy endorses the Arctic coastal states' July 2015 "Declaration concerning the prevention of unregulated high seas fishing in the Central Arctic Ocean" and recognizes the need for better scientific knowledge of the Arctic Ocean before commercial fisheries can begin. The Joint Communication does, however, specifically refer to the international status of the waters and encourages the consideration of appropriate international measures, such as the creation of a Regional Fisheries Management Organisation (RFMO) for the Arctic and/or the adoption of a Regional Sea Convention. Negotiations are currently underway to transform the 2015 Arctic fishing moratorium into a binding agreement and those negotiations have been broadened so as to involve other major fishing nations, including the EU. ${ }^{119}$ Furthermore, the Arctic Council Task Force on Arctic Marine

facilitates the sharing of information and fosters interaction between the European and Canadian research communities. For example, the ERA-Can II project hosted a Can-UsEU Symposium in September 2013 with the Canadian Embassy in Rome on "fostering transatlantic collaboration for the development and use of Arctic and marine research infrastructure." See the final report at <https:/ec.europa.eu/research/infrastructures/ pdf/Rome\%2oSymposium\%2oFinal\%2oReport.pdf $>$. The Alliance launched their second project to map the ocean seabed between Halifax, Nova Scotia and Tromsø, Norway, in 2015. Canada, Department of Fisheries and Oceans, 'Canada, U.S. and European Union Partners Complete Second Project under the Galway Statement' (Government of Canada, 25 August 2015) <http://www.dfo-mpo.gc.ca/media/infocus-alaune/2015/galway/indexeng.htm> accessed 24 October 2016.

117 JOIN (2016) 21, 6.

118 For background, see David VanderZwaag, Timo Koivurova, and Erik J. Molenaar, 'Canada, the EU and Arctic Ocean Governance: A Tangled and Shifting Seascape and Future Directions' (2009) 18 (2) Journal of Transnational Law \& Policy $247-87$.

119 Canada, China, Denmark, the EU, Iceland, Japan, South Korea, Norway, Russia and the us met in Washington in April 2016 to discuss plans to prohibit commercial fishing in the Central Arctic Ocean until scientists can learn more about the fish stocks and how they are changing. Hannah Hoag reports that "policy talks are discussing three different possible approaches: modifying the signed declaration to include other nations in a nonbinding agreement; drafting a new binding international agreement; and negotiating the creation of a regional fisheries management organization." According to the news report, "[b]oth the U.s. and Canada support a binding agreement on Arctic fisheries." 
Cooperation is currently assessing the need for a regional seas programme or other mechanism, as appropriate, for increased cooperation in Arctic marine areas. ${ }^{120}$ The EC Joint Communication also promotes the establishment of marine protected areas (MPAs) in the Arctic as essential tools for the preservation of Arctic biodiversity, which dovetails with PAME's strategic priority to develop a "pan-Arctic network of marine protected areas to strengthen marine ecosystem resilience and contribute to human well-being, including traditional ways of life."121

A significant aspect of PAME's approach to marine protected areas in the Arctic is its emphasis on areas of cultural significance and the explicit reference to the goal of enhancing the wellbeing of the Arctic's inhabitants and fostering traditional ways of life. The idea that environmental protection must not be considered in a vacuum, distinct and separate from the lives of the peoples of the Arctic, also lies at the heart of Canada's policy for its northernmost regions. Under the "Protecting our Environmental Heritage" pillar, Canada's two key priorities for the International Polar Year are identified: climate change impacts and adaptation; and, significantly, the health and wellbeing of Northerners and Northern communities. The Northern Strategy emphasizes that "Aboriginal people and Northerners played a significant role in the planning, coordination and implementation of the IPY and were actively engaged in science and research activities." Government programmes, funding bodies and researchers continue to tap into the traditional knowledge and expertise of the Arctic's Indigenous inhabitants.

The idea that Northerners must have a meaningful role in shaping the future of the Arctic region transcends each of the individual pillars of Canada's Northern Strategy and is highlighted in recent EU policy statements as well. Under the "Sovereignty" pillar, for instance, Canada's strategy acknowledges

Hannah Hoag, "Nations Negotiate Fishing in Arctic High Seas," News Deeply, 28 April 2016, <https://www.newsdeeply.com/arctic/articles/2016/04/28/nations-negotiate-fishing-in -arctic-high-seas $>$ accessed 24 November 2016. A second round of negotiations will be held in Iqaluit, Nunavut in July 2016.

120 Arctic Council, 'Interviews with co-chairs of the Task Force on Arctic Marine Cooperation' (Arctic Deeply, 29 October 2015) <http://www.arctic-council.org/index.php/en/our-work2/ 8-news-and-events/369-tfamc-co-chairs-interviews > accessed 24 October 2016.

PAME, Arctic Marine Strategic Plan (AMSP) 2015-25, Strategic Action 7.2.10 <http://www .pame.is/images/o3_Projects/AMSP/AMSP_2015-2025.pdf> accessed 24 November 2016. Annex 4 to the AMSP provides detailed information on existing and planned MPAs in the Arctic E Ezs of Canada, Denmark/Greenland, Iceland, Norway, Russia, and the United States and attests to the progress that has been achieved. The table "Existing MPAs" reveals that Canada has five MPAs covering $29,892 \mathrm{~km}^{2}$ of its Arctic EEz. 
that "Northerners have an important role to play in shaping regional priorities and actions." Under the "Promoting Social and Economic Development" pillar, the Canadian policy insists that "Northerners participate in and benefit from development" in the North. ${ }^{122}$ The Northern Strategy also recognizes the rights and political influence of Indigenous peoples within the Canadian political and legal system, pledging to continue to pursue the most innovative and consultative approaches for Northern governance. For its part, the EU's recent policy devotes two paragraphs to the need for meaningful consultation and participation under the heading "Dialogue with Arctic indigenous peoples." The opening sentence is perhaps the most critical, committing the EU to "continue to engage" with Arctic Indigenous peoples and local communities to ensure that "their views and rights are respected and promoted in the ongoing development of EU policies affecting the Arctic."123 This emphasis hopes to dispel lingering distrust stemming from the $\mathrm{EU}$ ban on the trade in seal products - the most obvious and politically contentious example of divergent Canada-Eu interests.

Sealing is a way of life and an important source of food and income for Canadian Inuit and for thousands of Canadian families in remote coastal communities. ${ }^{124}$ Although Canada insists that its seal harvest is lawful, sustainable, humane and strictly regulated, ${ }^{125}$ the EU adopted a general ban on the importation and sale of seal products in 2009 in response to popular concerns about the methods used to kill seals. Under this Eu regulation, seal products can be

\footnotetext{
122 Canada's Northern Strategy, 7-8.

123 JOIN (2016) 21, 15.

124 See, for example, Seals \& Nunavut: Our Tradition, Our Future (Nunavut Tunngavik, Ottawa 1999). See also comments by Jon Burgwald on behalf of Greenpeace Nordic via a blogpost on 21 January 2016: 'Indigenous communities have shown time and again that they understand how to protect the Arctic ecosystem they call home, and their hunting practices have never been a threat to seal or whale populations ... They hunt because it is a crucial way to sustain themselves and their families in the harsh Arctic environment'. Available at $<\mathrm{http}$ //www.greenpeace.org/canada/en/blog/Blogentry/where-does-greenpeace-stand-on-seal-hunting/blog/5536o/> accessed 24 October 2016.

125 The methods used by Canadian sealers and prescribed in Canada's Marine Mammal Regulations are based in part on the recommendations of the Independent Veterinarians Working Group (2005) and are consistent with the conclusions of the EU's European Food Safety Authority report released in 2007. Canada maintains that its enforcement of the regulations is thorough, comprehensive, and ensures adherence to catch requirements, licence conditions, and humane harvesting practices. Canada, Department of Foreign Affairs and International Trade, 'Questions \& Answers: Canada's World Trade Organization Dispute on the European Union Seal Ban-Public Release of Final Report' 25 November 2013.
} 
placed on the EU market only if a "recognized body" attests that the products result from hunts conducted traditionally by Inuit and other Indigenous communities or from hunts conducted for the sole purpose of sustainable management of marine resources on a non-systematic, not-for-profit basis. ${ }^{126}$ This appears to accommodate Indigenous rights, but the actual requirements for Canadian seal products to qualify under the Inuit exemption were unclear and Canadian Inuit groups forcefully argued that the European Economic Community's 1983 ban on harp seal pup skins (which allowed Inuit-derived products while banning all others) proved how a general ban effectively destroys the market for all seal products. ${ }^{127}$

Subsequent legal processes, which pitted public morality against the human rights of Arctic Indigenous peoples, widened the divide between the two sides. By provoking strong Inuit statements against the Eu's alleged disregard for the rights and livelihoods of Indigenous peoples in the Arctic, the dispute forced Canada to not only challenge the myths and misinformation that underlay the European position but also to mount legal challenges against what it considered to be an unfair law. ${ }^{128}$ When attempts to resolve the issue bilaterally

126 The import of seal products for personal use by travellers and in small quantities is also permitted. Notably, seal products from Canada's east coast commercial seal fishery would not qualify under either of the exemptions. European Parliament, Regulation (EC) No 1007/2009 of the European Parliament and of the Council of 16 September 2009 on trade in seal products, <http://trade.ec.europa.eu/doclib/docs/2009/november/ tradoc_145264.pdf> accessed 24 November 2016. It should be noted that amendments to the 2009 EU seal Regulation which came into effect on 18 October 2015 have eliminated the marine resource management exemption.

127 Government of Canada, 'Seals: Canada's Seal Hunt' (Government of Canada, last modified 25 March 2013) <http://www.canadainternational.gc.ca/eu-ue/policies-politiques/ seals-phoques.aspx?lang=eng > accessed 26 October 2016; and Canadian Arctic Resources Committee, 'The Anti-sealing Campaign' (1986) 14 (2) Northern Perspectives <http://www .carc.org/pubs/v14no2/2.htm> accessed 26 October 2016. Implementing the necessary certification structures and procedures to meet the requirements of the Inuit exemption under the $2009 \mathrm{EU}$ ban were expected to cost more than the possible export revenues generated in the long term.

128 For background on the case, see Peter Fitzgerald, 'Morality' May Not Be Enough to Justify the EU Seal Products Ban: Animal Welfare Meets International Trade Law' (2011) 14 (1) Journal of International Wildlife Law \& Policy 85-136; Nicolas Sellheim, 'The goals of the EU seal products trade regulation: From effectiveness to consequence' (2015) 51 (3) Polar Record 274-289; Kamrul Hossain, 'The Eu ban on the import of seal products and the Wто regulations: neglected human rights of the Arctic indigenous peoples?' (2013) 49 (2) Polar Record 154-166; Tamara Perišin, 'Is the EU seal products regulation a sealed deal? EU and wTO challenges' (2013) 62 (2) International and Comparative Law Quarterly 
failed, Canada and Norway challenged the Eu seal ban through World Trade Organization (WTO) dispute mechanisms ${ }^{129}$ and Inuit groups also questioned the legality of the ban under European Union laws. ${ }^{130}$ Although the EU defended its position, the legal battle with Canada elicited divergent perspectives within the Union about whether to insist that Canada withdraw its challenge before concluding a Canada-EU Comprehensive Economic and Trade Agreement (CETA). ${ }^{131}$

373-405; Xinjie Luan and Julien Chaisse, 'Preliminary Comments on the wTo Seals Products Dispute: Traditional Hunting, Public Morals and Technical Barriers to Trade' (2011) 22 Colorado Journal of Environmental Law \& Policy 79-121; and Sellheim, 'The neglected tradition?-The genesis of the Eu seal products trade ban and commercial sealing' (2013) 5 (1) Yearbook of Polar Law 417-450.

129 Following consultations between Canada, Iceland, Norway, the European Communities and European Union, Canada requested the establishment of a panel under the wTO Dispute Settlement Body (DSB) in February 2011. Its final report was circulated to WTO Members on 25 November 2013 and found that the European Union's ban on imports of Canadian seal products indeed violates its international trade obligations and confirmed that the EU ban is discriminatory and treats Canadian seal products unfairly, but the panel also decided that such a ban can be justified due to some of the public's concerns regarding seal harvesting. Canada and Norway appealed the report on 24 January 2014 and the Appellate Body issued its final ruling on 22 May 2014.

130 Separately, Inuit and affiliated groups (including the Inuit Circumpolar Council and Inuit Tapiriit Kanatami) filed applications at the European General Court for the annulment of the EU seal ban. The Court dismissed the first application as inadmissible in September 2011. In April 2013, the Court dismissed the second application on the basis that the "basic regulation is intended to improve the conditions for the establishment and functioning of the internal market by laying down harmonising rules for the placing on the market of seal products." On 3 September 2015, the Court of Justice of the European Union dismissed an appeal of the earlier decisions. See Court of Justice of the European Union, Press Release No. 93/15, 'The Court of Justice confirms the validity of the regulation on trade in seal products', (3 September 2015), <http://curia.europa.eu/jcms/upload/docs/ application/pdf/2015-09/cp150093en.pdf $>$ accessed 29 October 2016. The cJEU identified three technical legal grounds as justifying its dismissal and also ruled that "Article 19 of the United Nations Declaration on the Rights of Indigenous Peoples, which encourages members of the United Nations to obtain prior consent of those peoples before adopting or implementing measures that affect them, does not, in itself, have binding legal force." For a succinct summary of Inuit concerns, see Mary Simon, 'Speech: The European Union, Canada, and the Arctic: Challenges of International Governance' (23 September 2011) <https://www.itk.ca/media/speech/european-union-canada-and-arctic-challengesinternational-governance $>$ accessed 29 October 2016.

131 In June 2011, the European Parliament approved a resolution that expressed its strong hope that Canada would withdraw its challenge against the seal ban before a Canada-EU 
The seal dispute had a direct bearing on Canadian and Permanent Participant support for the EU's application for accredited observer status at the Arctic Council. While the Eu had been an ad hoc observer since 1998 (originally as the European Community), ${ }^{132}$ the European Commission formally applied to become a "permanent observer" in 2008 and its policy released that year identified this as an immediate priority. ${ }^{133}$ The prolonged Arctic Council deliberations on observer applications have been documented elsewhere, with recent scholarship confirming that Canada and Russia harboured deep reservations about the EU's application. In Canada's case, Inuit groups strongly urged the government to oppose it. ${ }^{134}$ "As long as [the] European Union doesn't have the required sensitivity to the needs of northerners," Canadian Foreign Affairs Minister Lawrence Cannon asserted in 2009, "I see no reason why they should be [...] a permanent observer on the Arctic Council."135 Accordingly, when the Arctic Member States and Permanent Participants considered fourteen applications for observer status at the Kiruna Ministerial Meeting in May 2013, the Arctic Council "received the application of the EU for observer

Comprehensive Economic and Trade Agreement (CETA) was ratified. Ashey Fitzpatrick, 'Seal hunt under fire again at European parliament' The Telegram (St. John's, 8 June 2011). That October, about 100 of the 735 members of the European Parliament signed an open letter condemning the Canadian seal hunt and advocating against supporting a CETA until Canada withdrew its wTo seal challenge $<$ http://www.hsi.org/assets/pdfs/hsi_canada_ meps_101711.pdf> accessed 24 November 2016. By contrast, the European Commission appeared to agree with Canada that the CЕтA negotiations and the wTо challenge were two separate issues. This distinction was clarified in discussions following Lackenbauer's presentation to Members of European Parliament on "Canada's Northern Strategy: Convergence or Divergence with EU Interests?” in Brussels, Belgium, on 23 March 2015.

132 J. Wouters et al., 'The Eu and International Organizations' in Michael Smith, Stephan Keukeleire, and Sophie Vanhoonacker (eds), The Diplomatic System of the European Union: Evolution, Change and Challenges (Routledge, London 2016) 103.

133 сом (2008) 763, 9 .

134 See, for example, Nunavut Tunngavik Inc., 'NTI Urges Canada to Deny the European Union's Application' (Nunavut Tunngavik, 25 April 2013) <https://www.tunngavik .com/blog/news/nti-urges-canada-to-deny-the-european-unions-application/> accessed October 26 2016. "The EU has demonstrated repeatedly that it does not support Canada's sustainable use of renewable resources," NTI President Cathy Towtongie stated. "The EU demonstrated this through its actions on Canada's seal hunt and its recent lack of support at Cites on the polar bear harvest."

135 Cannon quoted in СвС News, 'Canada against Eu entry to Arctic Council because of seal trade ban' ( свс News, 29 April 2009) <http://www.cbc.ca/news/canada/north/ canada-against-eu-entry-to-arctic-council-because-of-seal-trade-ban-1.806188 > accessed 26 October 2016. 
status affirmatively" but deferred a final decision on implementation until the Council ministers agreed by consensus that all of the concerns of Council members regarding the EU application were resolved. ${ }^{136}$ For Canada and various Indigenous groups, this equated to finding specific ways to address wellestablished concerns about the EU seal product import ban.

Since that time, the EU has repeatedly affirmed its clear intent to respect Indigenous interests and rights, and has sought regular dialogue with Permanent Participants to improve mutual understanding - without conceding on the seal issue. Prior to the final ruling of the wTo Appellate court in May 2014 (which upheld the previous ruling that the EU seal ban was "necessary to protect public morals"), ${ }^{137}$ the European Parliament passed a resolution acknowledging "the wish of the inhabitants and governments of the Arctic region with sovereign rights and responsibilities to continue to pursue sustainable economic development while at the same time protecting the traditional sources of the Indigenous peoples' livelihood and the very sensitive nature of the Arctic ecosystems." ${ }^{138}$ The EU Foreign Affairs Council conclusions on "Developing a European Union Policy towards the Arctic Region," adopted on 12 May 2014, called on the EU to explore "appropriate ways of ensuring that the representatives of Arctic Indigenous peoples are informed and consulted on EU policies that may affect them." It also urged Canada to use the current

${ }_{13} 6$ In the meantime, the decision noted that the EU could continue to observe Council proceedings.

137 The wто Panel and Appellate Body both rejected the claims of Canada and Norway against the ban itself. They accepted that the ban pursued a legitimate objective (public moral concerns on seal welfare) and was not more trade restrictive than necessary. However, as noted by the European Commission Directorate-General for Trade, "the Appellate Body found that there was a de facto violation of the most-favoured nation treatment obligation (Article 1 GATT) because seal products derived from Greenland were treated more favourably than seal products from Canada through the exception for products derived from Inuit hunts. It found that this difference in treatment could in principle be justified under the exception of GATT (Article $\mathrm{xx}$ ) for public morals but found that the $\mathrm{Eu}$ had failed to design the legislation to prevent arbitrary discrimination and should have made more efforts to encourage Canadian Inuit to use the exception." European Commission Directorate-General for Trade, 'WT/DS400-European Communities-Measures Prohibiting the Importation and Marketing of Seal Products' $<$ http://trade.ec.europa.eu/wtodispute/show.cfm?id=475\&code=2> accessed 29 October 2016. For a summary of the key legal findings in the case, see EC-Seal Products (DS40o, 401), available at <https://www.wto.org/english/tratop_e/dispu_e/cases_e/1pagesum_e/ ds40osum_e.pdf $>$, accessed 29 October 2016.

138 European Parliament, 'European Parliament resolution on the Eu strategy for the Arctic' (12 March 2014) 2013/2595(RSP) <http://www.europarl.europa.eu/sides/getDoc.do?type= TA\&language $=\mathrm{EN} \&$ reference $=\mathrm{P}$ 7-TA-2014-0236 $>$ accessed 29 October 2016 . 
positive momentum in EU-Canada relations to help resolve the remaining issue so as to allow for the full implementation of the Kiruna decision regarding the EU's observer status as soon as possible before the next EU/Canada summit."139 The remaining issue, not mentioned by name, was the seal ban.

The wто ruling, coupled with the necessity for consensus support in the Arctic Council for the EU to gain full observer status, encouraged both sides to broker an agreement to overcome the political imbroglio. For the EU, this meant ensuring Canadian Indigenous peoples were treated the same as any other Indigenous communities seeking access for their seal products in markets within the EU. Along these lines, the "Joint Statement by Canada and the European Union on Access to the European Union of Seal Products from Indigenous Communities of Canada," released in August 2014, set out "the framework for cooperation to enable access to the European Union of seal products that result from hunts traditionally conducted by Canadian Indigenous communities and which contribute to their subsistence." Under this agreement, both sides reinforced "the importance of preserving the traditional way of life of indigenous communities" and pledged to:

- pursue discussions on possible participation by Canadian partners in the new European Union Northern Periphery and Arctic Programme;

- explore possibilities for supporting indigenous communities and traditional ways of life through capacity building and exchange of best practices;

- explore how indigenous communities can benefit from the new opportunities to be opened up by the Canada-European Union Comprehensive Economic and Trade Agreement, to develop their economic, social, and environmental potential;

- explore how bilateral European Union-Canada research cooperation, including the incorporation of traditional knowledge, can bring benefits relevant to indigenous communities;

- identify other areas of mutual interest where exchange of expertise and dialogue could benefit indigenous communities, including the marketing of traditional products; and,

139 Council of the European Union, Foreign Affairs Council meeting, 'Council conclusions on developing a European Union Policy towards the Arctic Region' (12 May 2014) <http:// www.consilium.europa.eu/uedocs/cms_Data/docs/pressdata/EN/foraff/142554.pdf> accessed 26 October 2016. Paragraph 14 further invites the European Commission to ensure that EU programs relevant to the Arctic under the EU's 2014-2020 multi-annual financial framework "meet the development needs of local populations and offer better opportunities for circumpolar cooperation and research as well as Arctic economic development." 
- continue to engage in regular dialogue with representatives of indigenous communities, with a view to increasing mutual understanding. ${ }^{140}$

In its decision on the Joint Statement, the European Commission noted that, in return, Canada had agreed to "lift its reservations concerning the EU's observer status in the Arctic Council."141

Since 2014, progress has been made on implementing this agreement ${ }^{142}$ and the EU continues to emphasize the importance of substantive dialogue with Arctic Indigenous peoples. Its 2016 policy expresses a clear commitment to "engage with Arctic indigenous peoples and local communities to ensure that their views and rights are respected and promoted in the ongoing development of EU policies affecting the Arctic."143 The annual EU Arctic Indigenous Peoples Dialogue meetings between the European Commission and representatives of Arctic Indigenous peoples, held since 2013 to exchange views and agree on areas for further cooperation, have been helpful in building trust and mutual understanding. The Joint Communication also urges the EU to continue to work "on advancing consistency between the EU's internal and external policy towards indigenous peoples."144 For Inuit, who depend on the harvest of sea mammals to provide a livelihood for their families and to maintain their culture and quality of life, this commitment may be tested if a longstanding debate reignites over the commercial trade in polar bears.

Canadian Inuit do not support the us proposal to transfer the polar bear from Appendix II to Appendix I of the Convention on International Trade

140 See Annex 1: 'Joint Statement by Canada and the European Union on Access to the European Union of Seal Products from Indigenous Communities of Canada' to the European Commission Decision, (2014), C(2014) 5881 final <http://eeas.europa.eu/canada/docs/ joint_statement_c_2014_5881_fi_annex_en.pdf > accessed 29 October 2016.

141 European Commission Decision on the Joint Statement by Canada and the European Union on Access to the European Union of Seal Products from Indigenous Communities of Canada, 18 August 2014, C(2014) 5881, <http://www.embassynews.ca/sites/embassy news.ca/files/Commission-Decision-Joint-Statement.pdf> This page is no longer available, copy on file with the authors.

142 In July 2015, the EU formally approved the Government of Nunavut as a Recognized Body under the Indigenous Communities Exemption of the Eu Seal Regime, meaning that the latter would be able to certify sealskins as having been harvested according to the rules of the exemption. Fisheries and Oceans Canada, 'Government of Canada Congratulates the Government of Nunavut on Important Step to Securing Access to European Markets for Seal Products' (Government of Canada, 31 July 2015) <http://news.gc.ca/web/article-en .do?nid=1014449> accessed 26 October 2016.

143 JOIN (2016) 21,15. Emphasis in the original.

144 Ibid. 
in Endangered Species of Wild Fauna and Flora [CITES] ${ }^{145}$, which would ban all commercial trade. Canada's national Inuit organization, Inuit Tapiriit Kanatami (IтK), maintains that the species does not meet the criteria for an Appendix I listing: the polar bear is well-managed, and the hunt remains within sustainable levels and does not pose an existential threat to the species. ${ }^{146}$ The EU, which votes as a block registering 28 votes, helped defeat the Us proposal in March 2010. The us resubmitted its proposal at the 16th CITEs Conference of the Parties [CoP16] in March 2013, and without EU support it once again failed to garner the required two-thirds majority. The EU's action on this occasion, however, simply reflected a lack of consensus among the European Member States, with the EU tabling an alternative proposal at the same meeting to keep the polar bear in Appendix II but with export limits for each management unit in Canada and providing for a review of trade impacts by CITES to identify further actions. The EU alternative proposal also failed to achieve a two-third majority and was rejected; the polar bear thus remains listed under Appendix II and the controlled trade of polar bear parts has been maintained. Although no proposal to uplist polar bears was submitted to the Cites $\mathrm{CoP} 17$ in South Africa in October 2016, ${ }^{147}$ the issue may resurface in the future.

Future trends are inherently speculative, but it is appropriate to conclude that EU policies have moved into closer alignment with those of Canada, and vice versa (particularly on issues of climate change mitigation and sustainable energy development). While the European Parliament's past messaging raised

145 Convention on International Trade in Endangered Species of Wild Fauna and Flora (adopted 3 March 1973, entered into force 1 July 1975) 993 UnTs 243.

146 According to the ITK fact sheet, not only have polar bear numbers not significantly declined but rather there has been a significant increase over the past forty years with the population currently estimated at $20,000-25,000$ individuals. Canada is home to $65 \%$ of the world polar bear population and only $2 \%$ of that population, roughly 300 animals, enter the market each year. And within the Canadian Arctic, polar bear hunting quotas and tags are allocated exclusively to Inuit communities. See Iтк, 'Polar Bears, Harvesting and Inuit' (Inuit Tapiriit Kanatami) <https://www.itk.ca/about-itk/dept-envi ronment-and-wildlife/polar-bears/polar-bears-harvesting-and-inuit> accessed 29 October 2016. On Canada's conservation measures regarding polar bears, see Environment and Climate Change Canada, 'Conservation of Polar Bears in Canada' (Environment Canada, 2012) <https://www.ec.gc.ca/Publications/14C22559-9427-4476-9D85E783E03106B8/Con servationOfPolarBearInCanada.pdf> accessed 26 October 2016.

147 See Makivik Corp., 'Makivik Congratulates Fellow Canadian Inuit on Continued Polar Bear Trade' (Makivik Corporation, 2 May 2016) <http://www.makivik.org/inuit-continuedpolar-bear-trade/> accessed 26 October 2016; Sima Sahar Zerehi,' Inuit applaud U.s. decision not to push polar bear trade restrictions' ( .ca/news/canada/north/inuit-applaud-us-decision-polar-bear-trade-1.3562940> accessed 26 October 2016; 
legitimate concerns in Canada about the EU's grasp of circumpolar governance, sovereign rights, and Indigneous peoples, the recent Joint Statement reveals a nuanced and mature appreciation of circumpolar affairs. In response, Timo Koivurova recently noted, "the time has come for Arctic states to understand the European Union and acknowledge its investments in research, development, and education in the region, and its contribution to Arctic governance. It should be formally accepted as an observer to the Arctic Council." 148 Canada agrees, with outgoing Arctic Council chair Leona Aglukkaq unambiguously stating in April 2015 that "Canada supports the EU application for full observership [sic]."149 Although the Arctic Council again deferred its final decision on the EU's application at the Iqaluit Ministerial that month, this was a reflection of the frosty relations with Russia since the EU imposed sanctions on that country in September 2014 over the Ukraine crisis. In short, Canada is no longer a primary roadblock to EU Arctic aspirations and, in areas of common interest, is likely to become a more enthusiastic partner.

\section{7}

\section{Conclusions}

The popular media and academic literature typically depicts the Canadian-EU Arctic relationship as confrontational. This narrative is largely unjustified or, at the very least, reflects insufficiently nuanced understandings of both parties' motives and aspirations. It is our hope that such unflattering and harsh assessments have now been laid to rest. Indeed, the Joint Declaration signed on 26 September 2014 by Prime Minister Harper, European Commission President José Manuel Barroso and European Council President Herman Van Rompuy to celebrate the end of negotiations of the Canada-European Union Trade Agreement seems to portend a new era of cooperation and mutual understanding:

We, the leaders of Canada and the European Union ... are committed to strengthening and deepening our strategic partnership that builds on our shared history and values. We reaffirmed our commitment to contributing to our mutual prosperity through our continued cooperation.

148 Timo Koivurova, 'The EU in the Arctic: Correcting Misconceptions' (Arctic Deeply, 29 February 2016), <https://www.newsdeeply.com/arctic/op-eds/2016/o2/29/the-eu-in -the-arctic-correcting-misconceptions $>$ accessed 26 October 2016.

149 Quoted in Lily Haines, 'EU bid to become Arctic Council observer deferred again' (Barents Observer, 4 May 2015) <http://barentsobserver.com/en/arctic/2015/05/eu-bid-become -arctic-council-observer-deferred-again-04-05> accessed 26 October 2016. 
We welcome the deepening ties in Arctic cooperation, including through the Arctic Council. The EU and Canada are strategic partners in the field of research and innovation ... This Ottawa Summit has given renewed voice and vision to our partnership, and has positioned us to work more closely and effectively together across a range of priority areas, for the prosperity and security of our peoples, and the global community. ${ }^{150}$

Although Canada and the EU have displayed strong differences on several Arctic issues and policy areas over the last decade, we suggest that recent political and policy trajectories point to increasing policy convergence related to the region. Our overview of the main tenets of Canada's integrated Northern Strategy suggests a fairly consistent approach to Arctic affairs that reflects particular views about sovereignty, security, indigenous rights, economic development, environmental protection, and governance borne of its historical and contemporary experiences. Bringing Canada's interests into dialogue with $\mathrm{EU}$ Arctic policy, particularly the integrated policy released in April 2016, helps to counter the pervasive perception of conflicting agendas writ large.

The EU's 2016 Arctic policy notes that "sustainable development faces specific challenges in the Arctic region." Although this statement applies across the circumpolar Arctic, on this particular theme the EU seems reticent to project a vision for the region as a whole. Instead, it refers repeatedly to "the European part of the Arctic," with little to no reference to the North American Arctic (apart from Greenland). ${ }^{151}$ While this avoids criticism from Canadians that the $\mathrm{EU}$ is seeking to impose a European view of development on the circumpolar world as a whole, it also entrenches the idea that the ideal of "One Arctic" (enunciated by both the Inuit Circumpolar Council and the U.s. Arctic Council chairmanship for 2015-17) must be supplemented by regional variations that reflect multiple Arctics. In Canada's case, criticisms that its Arctic agenda is relentlessly domestic or North American in its assumptions and priorities also suggest the need to articulate and promote a more holistic, comprehensive view to address truly circumpolar challenges. Although some diverging interests, as well as competing interpretations of relevant rules, may be inevitable, we contend that these legitimate points of policy friction need not hinder Canadian-EU collaboration in the Arctic, particularly around the priority areas of climate change and environmental safeguards, science and technology, sustainable development, and international cooperation more broadly.

\footnotetext{
$15^{0}$ Available on the website of the Government of Canada, available at <http://news.gc.ca/ web/article-en.do?nid=888399 $>$. Emphasis added.

151 JOIN (2016) 21, 8-13.
} 